Can Budget Institutions Counteract Political Indiscipline?

Stefania Fabrizio and Ashoka Mody 

IMF Working Paper

European Department

\title{
Can Budget Institutions Counteract Political Indiscipline?
}

\author{
Prepared by Stefania Fabrizio and Ashoka Mody ${ }^{1}$
}

May 2006

\begin{abstract}
This Working Paper should not be reported as representing the views of the IMF. The views expressed in this Working Paper are those of the author(s) and do not necessarily represent those of the IMF or IMF policy. Working Papers describe research in progress by the author(s) and are published to elicit comments and to further debate.

The budget is an expression of political rather than economic priorities. We confirm this proposition for a group of new and potential members of the European Union, finding that politics dominates. The contemporary practice of democracy can increase budget deficits through not only ideological preferences but also more fragmented government coalitions and higher voter participation. Long-term structural forces, triggered by societal divisions and representative electoral rules, have more ambiguous implications but also appear to increase budget pressures, as others have also found. However, our most robust, and hopeful, finding is that budget institutions - mechanisms and rules of the budget process - that create checks and balances have significant value even when the politics is representative but undisciplined, and when long-term structural forces are unfavorable.
\end{abstract}

JEL Classification Numbers: D70, E60, H60

Keywords: Fiscal policy, budget institutions, electoral rules, government fragmentation, government ideology, ethnic fractionalization, voter turnover

Author(s) E-Mail Address: amody@imf.org; sfabrizio@imf.org

\footnotetext{
${ }^{1}$ Both authors are from the European Department, International Monetary Fund. The authors are especially grateful to Guido Tabellini for discussions that led to this paper and for his generous help with programs that allowed the research to be jump-started. They are also grateful to Giuseppe Bertola, Philippe Martin, and two anonymous referees for their comments on an initial draft, and for further comments from Mark de Broeck, Xavier Debrun, Mark Hallerberg, Robert Franzese, participants at the Political Economy of International Finance workshop held at Ann Arbor, Michigan, in October 2005, and for comments from seminar participants at the European Central Bank, the International Monetary Fund, the Magyar Nemzeti Bank, and the Reserve Bank of India. Michael Laver and Ken Benoit generously shared their ideology data. This draft is a preliminary version of a paper prepared for the $43^{\text {rd }}$ Panel Meeting of Economic Policy in Vienna on April 20-21, 2006.
} 


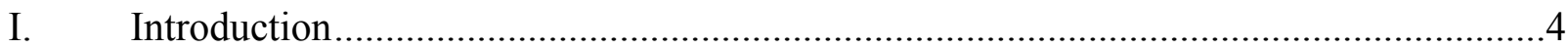

II. The Determinants of Fiscal Performance: A Selective Literature Review.....................7

A. Structural Determinants ........................................................................

B. Contemporary Politics....................................................................... 8

C. Budget Institutions and Fiscal Performance..........................................10

III. Budget Institutions in New and Potential EU Member States ...................................11

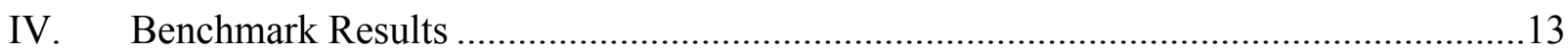

A. Economic Influences...................................................................... 15

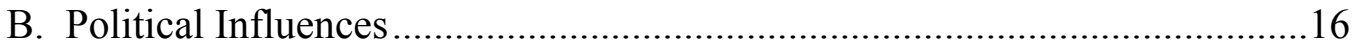

C. Economics Versus Politics ................................................................ 17

V. The Role of Deeper Determinants: Time-Invariant Factors ....................................18

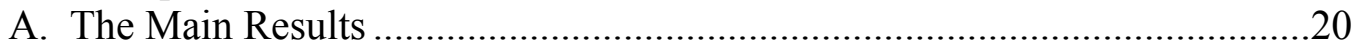

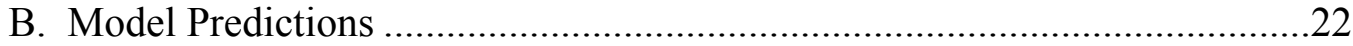

C. Components of the Budget Institutions Index .......................................23

VI. Differentiating the Effects of Expenditures and Revenues......................................24

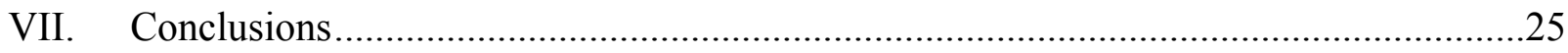

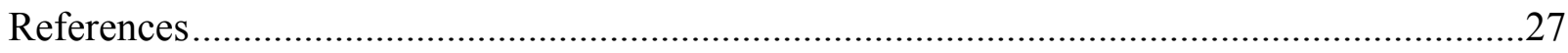

Boxes

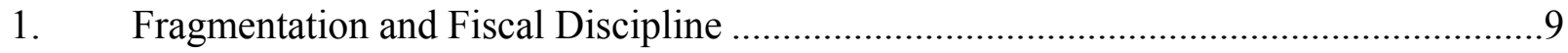

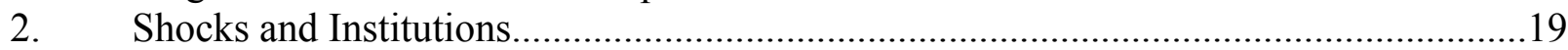

3. Observable Shocks, Institutions, and the Evolution of Expenditures and Revenues......24

Tables

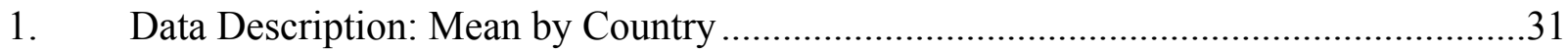

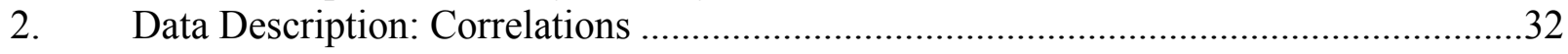

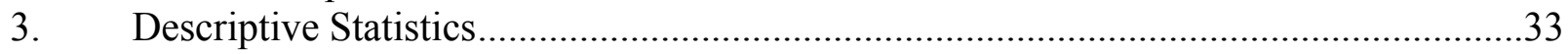

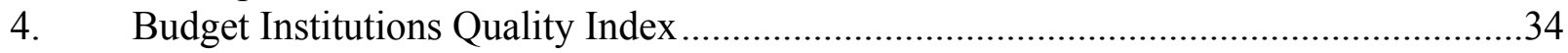

5. Economics, Politics, and Fiscal Performance: Evidence from Cross-Country Regressions ............................................................................................... 35

6. Economic Factors, Budget Institutions, and Fiscal Performance: Evidence from Panel Data Regressions (Fixed Effects)............................................................36

7. Government Fragmentation, Ideology, and Fiscal Performance: Evidence from Panel Data Regressions (Fixed Effects). 
8. Explaining Fiscal Performance: Economics Versus Politics, Evidence from Alternative Panel Data Estimation Procedures.

9. Explaining Fiscal Performance: Economics Versus Politics, Evidence from Panel Data

Regressions (Fixed Effects)

10. How Important Are the Deeper Determinants? Evidence from Nonlinear Least Squares

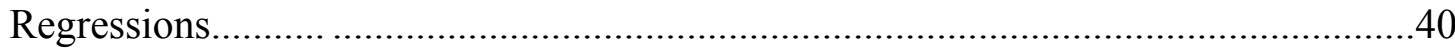

11. How Important Are the Deeper Determinants? Evidence from Nonlinear Least Squares

Regressions ..................................................................................................4

12. Budget Process Stages and the Delegation/Contract-Based Approaches: Evidence

from Nonlinear Least Squares Regressions ..........................................................42

13. Expenditure and Revenue Developments: The Role of Economics and Politics, Evidence from Panel Data Regressions (Seemingly Unrelated Regressions

Estimates)

14. Expenditure and Revenue Developments: The Role of Economics and Politics, Evidence from Panel Data Regressions (Seemingly Unrelated Regressions Estimates).

Figures

1. General Government Expenditure and Per Capita GDP, 2003 .................................5

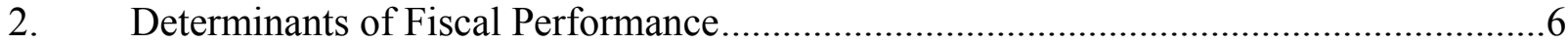

3. Hungary: Budget Institutions and Fiscal Performance, 1997-2003 ...........................13

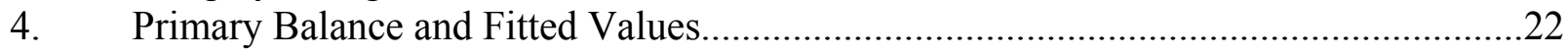

Appendices

A. Construction of the Budget Institutions Index.................................................45

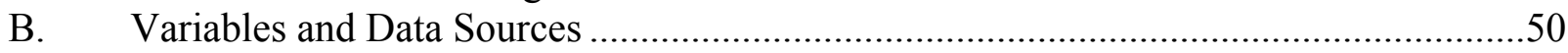

Appendix Tables

A1. Construction of the Index: Fiscal Institutions and Their Index Parameters......................48

A2. Construction of the Index: Scores ................................................................................49 


\section{INTRODUCTION}

Political economists find that constitutional provisions determining electoral rules play an important role in determining fiscal outcomes, both directly and indirectly through their impact on the form of government (Persson and Tabellini, 2003, 2004). Thus, politically more representative electoral rules achieve inclusiveness but at the cost of reduced political and fiscal discipline. Aghion, Alesina, and Trebbi (2004) find that the electoral rules are themselves the consequence of deeper structures in society. Where societies are divided along ethnic or religious lines, electoral rules are likely to be chosen to accommodate those interests, leading, in turn, to coalitional governments and a competition for fiscal resources. These are important, though pessimistic, findings. Since societal characteristics evolve slowly, and constitutions are, rightly, not often changed, the political processes they set in motion develop strong inertia and, by implication, so does budgetary performance.

In this context, then, does policy have a role? If policies map directly from history and politics, then they may merely be "veils" or "epiphenomena," with no substantive consequence. Even if they do have an independent bearing on outcomes, do policy measures offer the possibility of changing course despite the strong influence of history and politics? And, if so, for countries seeking to improve their fiscal position, what measures are likely to work?

In parallel, another group of scholars has examined whether budget formation rules influence fiscal performance (Alt and Lowry, 1994; Poterba, 1994; von Hagen and Harden, 1995; Hallerberg and von Hagen, 1999; Alesina, Hausmann, Hommes, and Stein, 1999; Stein, Talvi, and Grisanti, 1999). They find that checks and balances in the formulation and implementation of the budget are not veils or epiphenomena, and have real effects on budgetary outcomes.

Our contribution is twofold. First, we isolate the role of the budgetary institutional structure, while controlling for a more comprehensive set of economic and political conditioning factors than has been possible to use in past studies. Thus, Persson and Tabellini $(2003,2004)$ examine the influence of electoral rules but not of budget institutions; Perotti and Kontopoulos (2002) analyze government fragmentation and ideologies, as well as fiscal institutions, but do not consider electoral rules. Where, in principle, all factors are considered, as in Alesina, Hausmann, Hommes, and Stein (1999), the findings are based on a cross-section of about 20 countries.

Second, we focus the empirical analysis on an important context: the new and potential member states of the European Union between 1997 and 2003. In anticipation of their accession to the European Union on May 1, 2004, the new member states made a commitment to budgetary discipline. This ongoing process - culminating in their commitment to adopt the euro-represents an important historical experiment. However, despite the commonality of this commitment, there has been no uniform tendency toward convergence to specific quantitative budgetary benchmarks. Estonia, for example, has managed its public finances well, even running a primary surplus in some years. Poland improved its fiscal position in the late 1990s, running a surplus in 1999 and 2000, but drifted back to deficits thereafter. Hungary's budget balance has generally worsened over the time span covered in this paper. The countries also 
have different legacies. While the Baltic nations have small governments, Hungary and Poland and, to a lesser extent, the Czech Republic have large government sizes (expenditure/GDP) that lie above the line showing the tendency for governments to be bigger as per capita incomes increase (Figure 1).

For these countries, the challenges ahead are significant, not least because they have adopted proportional electoral rules, which, though varying in degree across countries, increase the likelihood of coalitional governments and, hence, generate pressures on the budget.

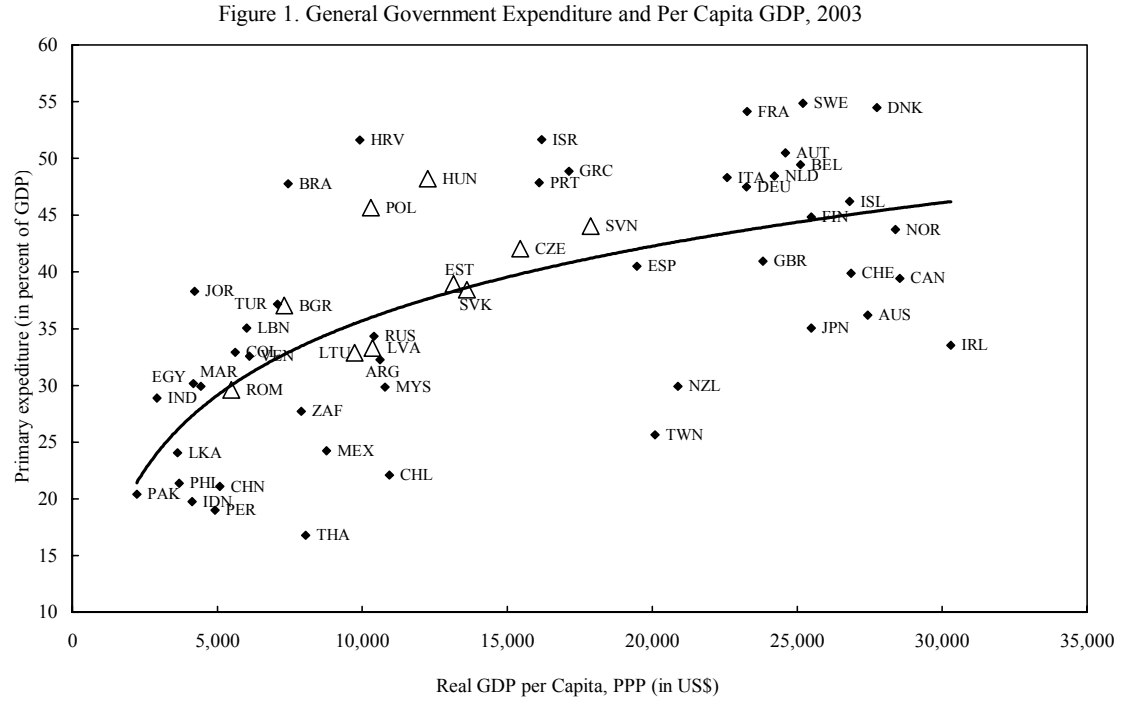

The empirical focus on

this small set of central and eastern European countries has its limitations, but also has benefits. The concern - and it is an important one-is that the data do not contain enough information to enable us to draw the kinds of conclusions we would like. We are encouraged, however, by the surprising robustness of the principal findings and their consistency with a broad range of studies that have had a narrower focus. The results strengthen the prima facie basis for specific institutional or rule-based measures to curb fiscal pressures and for further investigations of this kind on a broader set of countries. The advantage of this sample, making the results of potentially more general interest, is the time-series variation in the quality of fiscal institutions. As part of their reform agenda for transition to market economies, some countries improved their fiscal institutions, though the extent and pace of change varied considerably and some experienced slippages. Thus, while past studies have relied heavily on the cross-sectional relationship between budget institutions and fiscal performance, this sample allows us to relate their evolution to fiscal performance. At the same time, to guard against the risk of omitted variables, we also evaluate the role of time-invariant country characteristics in transmitting shocks to budgetary outcomes, using an approach developed by Blanchard and Wolfers (2000) and adapted to this context by, among others, Persson (2002, 2004), Persson and Tabellini (2003, 2004) and Milesi-Ferretti, Perotti, and Rostagno (2002).

Also of broader methodological interest is the multidimensional characterization of the historical and political determinants of fiscal performance. We find that the influences of these variables are more sharply discernible when they are considered as groups rather than as individual variables. This, we conjecture, reflects the fact that history and politics have a variety of direct and indirect impacts on policy formulation. While the grouping of variables remains ad hoc, we are struck, in particular, by the interactions between the degree of coalitional fragmentation and ideology, the latter itself best represented as a vector that 
included, in our case, the traditional left-right distinction along with the degree of nationalism and the attitude toward fiscal decentralization.

We reach three main conclusions. First, of greatest interest to policymakers, the quality of institutions continues to matter strongly in determining fiscal outcomes, even when we consider a variety of conditioning variables. Second, contemporary politics is important and appears to trump the economic conditioning variables. In particular, more fragmented government coalitions, and those with an ideological disposition toward the "left," toward a higher degree of nationalism, and toward greater fiscal decentralization, tend to be less fiscally conservative. Greater voter participation - a desirable attribute of a vibrant democracyappears to loosen the budgetary purse strings, as discussed in Mueller and Stratmann (2003). Third, "deeper" historical and political influences - ethnic fractionalization and the district magnitude (the number of representatives elected per district) - support the idea that more inclusiveness hurts budgetary outcomes; however, the results are unstable, possibly reflecting theoretical ambiguity in the relationships and, more likely, the absence of time variation in these variables in the small country sample. In sum, then, while contemporary democratic practice and long-standing political and societal characteristics have a significant bearing on fiscal outcomes, the more hopeful message of this paper is that policy initiatives that lay out checks in the competition for fiscal resources can materially help. These relationships are summarized in Figure 2.

Figure 2. Determinants of Fiscal Performance

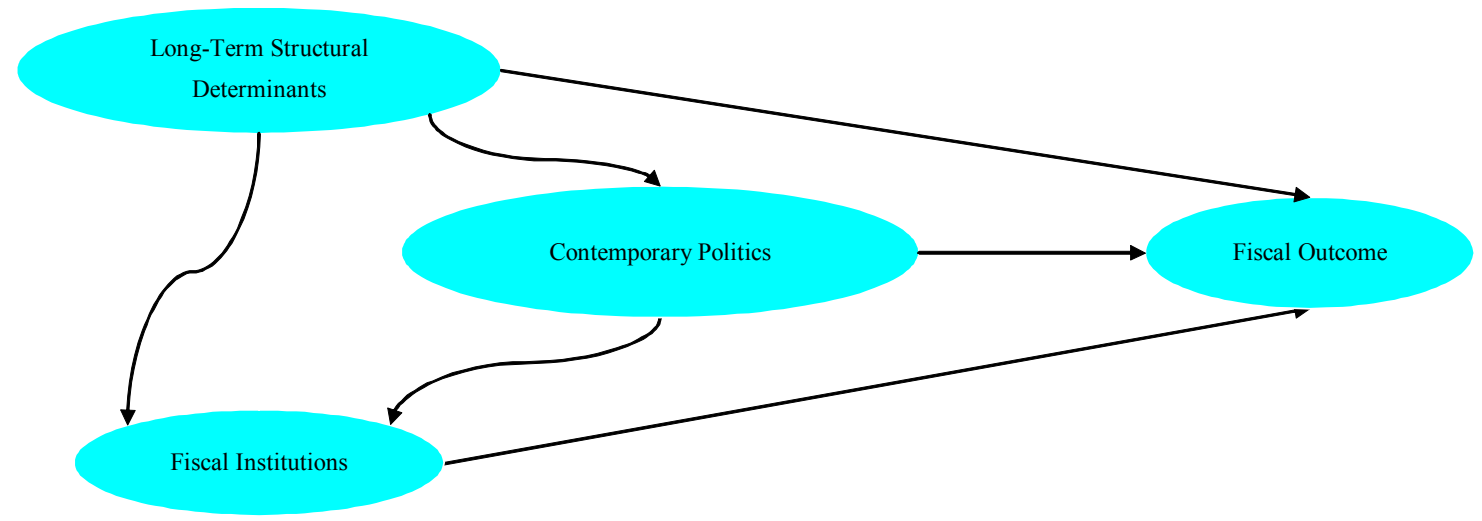

The rest of this paper proceeds as follows. Following the representation in Figure 2, Section II first reports the conclusions of earlier research on the influence of structural features and contemporary politics on fiscal outcomes; and then takes a closer look at the role of fiscal institutions in containing fiscal pressures in representative democracies. Section III describes the cross-country and over-time variation in fiscal institutions in our sample countries. The next three sections report the empirical results. Section IV presents the benchmark findings relating the variations in the economic, political, and budgetary institutions variables to the evolution of the fiscal balance. Section V considers the possibility that factors that do not vary over time nevertheless have time-varying effects, because they condition the transmission of 
shocks to the fiscal balance. And Section VI examines the influence of these same determinants separately on government revenues and expenditures. A final section concludes.

\section{The Determinants of Fiscal Performance: A Selective Literature Review}

As Figure 2 depicts, a variety of factors operate - in direct and indirect ways - on budgetary outcomes. The theory, moreover, is often ambiguous whether these effects, singly or in combination, raise or lower budget deficits, suggesting important nonlinearities. To help guide a parsimonious empirical analysis, this section summarizes the theoretical propositions that have found empirical support. We begin with a description of "structural" variables - those that change little over time and, moreover, condition the practice of politics in the country. Next, however, we note that democratic practice tends to have its own short-term dynamics, with (possibly independent) implications for fiscal decisions. Finally, we discuss whether fiscal institutions are merely a veil or can contain politics in democratic societies.

\section{A. Structural Determinants}

The principal tension arises from the balance a democracy must strike between achieving broad representation while maintaining fiscal accountability. Dealing with this tension are two themes in the literature: the diversity of the population and the design of the electoral systems. Population diversity creates pressures for greater representativeness but potentially weakens fiscal discipline. In turn, the political institutions in place determine how such dilemmas are resolved, or aggravated. Aghion, Alesina, and Trebbi (2004) suggest that divided societies create offsetting mechanisms to contain the ill effects of their divisions - though, in the process, compromise the extent of representativeness. They highlight, in this context, the key role of the electoral system, which by defining the rules of political engagement, is central to establishing the balance between representation and accountability. In their influential studies, Persson and Tabellini (2003, 2004) and Persson, Roland, and Tabellini (2005) outline the mechanisms through which electoral systems influence fiscal outcomes and report on the empirical strength of these mechanisms.

Electoral systems are pivotal in determining the number of parties contesting elections and the fragmentation of ruling coalitions. The feature of electoral systems that has drawn most attention is the proportionality of the electoral rule, though it is recognized that electoral systems do differ in other important ways (Lijphart, 1994; Hallerberg and Marier, 2004; and Persson, Roland, and Tabellini, 2005); especially, Hallerberg and Marier (2004) caution that the relationships may be nonlinear. In a majoritarian system, voters in a district elect one candidate to the legislature. Increasing proportionality (district magnitude) implies an increasing number of candidates per district (elected in proportion to the votes received) and, hence, increasing voice for an individual voter. In the limit, the whole nation serves as one district, with each vote counting in the party's national share of votes and, therefore, toward its allocation of seats in the legislature. Thus, proportional elections foster "representativeness," while majoritarian elections are thought to encourage "accountability." 
Consistent with this view, Persson and Tabellini (2003, 2004) find, in a cross-country setting, that majoritarian systems are associated with greater fiscal discipline than are proportional systems. Persson, Roland, and Tabellini (2005) further conclude that electoral systems do not have a direct effect on fiscal outcomes; rather, the influence is indirect: greater proportionality induces more parties into the electoral process and into the ruling coalition, with a tendency to higher public expenditures.

This is not good news for the countries we consider. Not one of them has a majoritarian system. The average district magnitude is 29, with a low of 8 in Bulgaria and Romania and a high of 150 in the Slovak Republic (Table 1). Hallerberg and Marier (2004), however, raise the possibility that representativeness and accountability may both improve when the degree of proportionality increases from low levels, with the trade-off kicking in only beyond a threshold. Note also that the correlation between ethnic fractionalization and district magnitude is weak in our sample of countries (Table 2), implying that the effects of diversity are not mediated predominantly through electoral systems.

\section{B. Contemporary Politics}

Persson, Roland, and Tabellini $(2005$, p. 26) show that "... there is considerable time variation in the type of government, which cannot be easily explained by sluggish electoral rule variables." This is true in our context, where electoral rules have not changed during the sample period but the "within-country" variation in the degree of government fragmentation and government ideologies is significant (Table 3 ).

Both the theory and the international evidence create a presumption in favor of contemporary politics as a crucial force in determining fiscal outcomes. The theory focuses on the effects of political fragmentation, concluding that more fragmentation allows greater scope for multiple constituencies to exercise claims on limited fiscal resources without bearing the full cost of the taxation needed to cover the benefits received (see Box 1). The evidence is supportive. In an early contribution, Roubini and Sachs (1989) found a tendency for more fragmented government coalitions to run larger budget deficits. Subsequent cross-country studies have validated this conclusion (see, for example, Hahm, Kamlet, and Mowery, 1996; Alesina, Hausmann, Hommes, and Stein, 1999; and Perotti and Kontopoulos, 2002, though the latter find a larger number of ministries the more relevant indicator of fragmentation than the number of parties in a governing coalition). An extensive literature has exploited differences in political configurations across states in the United States and has similarly found public spending pressures associated with political fragmentation (see Alt and Lowry, 1994; Poterba,1994; and Besley and Case, 2003, for a survey of the literature). 


\section{Box 1: Fragmentation and Fiscal Discipline}

In an analogy with use of nonrenewable resources, the budget, it has been suggested, is subject to a common-pool problem (Shepsle and Weingast, 1981 and Weingast, Shepsle, and Johnson, 1981). The problem is a simple one: where many can claim access to a resource from which they benefit but for which they pay only a part of the cost, there will be pressure to overconsume that resource. In the context of a budget, there will be a tendency to increase public spending in favor of interest groups who bear only a portion of the taxes needed to finance the expenditures that benefit them. The larger the number of interest groups, the greater the spending that will be induced. In a dynamic model with multiple constituencies, Velasco (1999) concludes that the spending pressures will, in the short run, lead to a drawdown of the national wealth (or an accumulation of debt). A country will continue to run deficits even as debt is being accumulated and will respond to the eventual need to repay that debt only when it has crossed a certain threshold - when the "writing is on the wall," at which point distortionary taxes will need to be raised.

These difficulties are aggravated by political parties and coalitions. Hallerberg and von Hagen (1999) note that short-term discipline will be worse when the governing parties can shift taxes onto the constituents supporting other parties. Persson, Roland, and Tabellini (2005) focus on competition within coalitions. A coalition member has an incentive to provide public goods or subsidies directed narrowly at its constituents to ensure their continuing loyalty. The costs arising from this competition are borne, in part, by coalition partners (who suffer electoral losses) and by the general taxpayer. Since all members of the coalition have the same spending incentives, a coalitional government will end up spending more than a single-party government.

Moreso than with coalitions, ideological predispositions do not follow in any simple manner from structural conditions. Though several authors test the effect of the traditional left-right distinction, the results have been ambiguous. This is not surprising. As Cukierman and Tomassi (1998) argue, just as it took "a Nixon to go to China," leftist governments may be more credible in persuading their constituents on the urgency and value of budgetary conservatism. Also, ideology need not be unidimensional. For example, there is no necessary relationship between the traditional left-right distinction and the degree to which governments favor fiscal decentralization or promote nationalism. Table 2 reports correlations along these ideological dimensions.

Finally, Mueller and Stratmann (2003) find that higher voter participation in elections has been associated with larger governments and slower growth. Greater participation increases the pressure on governments to deliver for their constituents. A more cynical view is that increased participation is associated with greater involvement of uninformed voters, leading to worse 
policies. Either way, wider representation once again appears to conflict with policy discipline. Though voter participation can, and does, change from one election to another, in practice, the variations in our sample of countries have been small. As such, we treat it as an unchanging variable, but one that differentiates countries.

\section{Budget Institutions and Fiscal Performance}

If a politically desirable increase in representation is accompanied by undesirable fiscal outcomes, can this unpleasant trade-off be alleviated? Fiscal institutions - the rules and procedures of budget formation — offer a possibility. These institutions, Poterba (1996, p. 47) suggests, are a form of "self control" imposed by fiscal actors on themselves. The aim, Eichengreen, Hausmann, and von Hagen (1999, p. 425) note, is not to "depoliticize" fiscal decision making but rather to improve the quality of decisions. This leaves open the question whether fiscal institutions can have real effects. In other words, even if sensible rules and procedures are set up, will self-interested political actors work around them to nullify their effectiveness? The international evidence and that from the U.S. states is that fiscal institutions do matter, as Alesina and Perotti (1999) report.

The institutional structures of the budget process determine the strategic choices and behavioral incentives of politicians and, thereby, influence the policy outcomes arising from collective decision-making processes. To overcome the common-pool problem (Box 1) and promote fiscal discipline, two perspectives have received attention (see, among others, Hallerberg and von Hagen, 1999). At one extreme, under the centralized, or delegation, approach, the common-pool problem is mitigated by concentrating budgetary power in the hands of key policymakers (e.g., the prime minister or finance minister), who have an incentive to internalize the costs and benefits of public activities. ${ }^{2}$ At the other extreme, under a more decentralized approach, cooperative decision making is achieved when policymakers internalize the spending externality by collectively negotiating and committing themselves to detailed multiannual fiscal targets. These two principles, combined with structures and devices to transparently and efficiently monitor and enforce budget decisions, promote fiscal discipline.

The form in which the common-pool problem is resolved, Hallerberg and von Hagen (1999) argue, should depend on the type of government. A strong finance minister, they suggest plays a critical role in one-party governments, since factions within a party have fewer policy disagreements and it is easier for the party to credibly delegate budgetary power to a central

\footnotetext{
${ }^{2}$ Formally, a strong and responsible finance minister is able to shift the weight of decision making to the optimal utility function away from the utilities accorded to individual constituents (see Hallerberg and von Hagen, 1999). Franzese (1999) models an independent central bank as one that is able to shift the weight of decisions toward the common good and away from the disparate interests of politicians. Not surprisingly, the call has been made for national fiscal councils to mimic independent central banks (see Eichengreen, Hausmann, and von Hagen, 1999; Annett, Decressin, and Deppler, 2005; and Wyplocz, 2005).
} 
player such as the finance minister. However, in coalition governments - and especially in minority-coalition governments - a "strong" finance minister may be infeasible. A particular coalition partner may be unwilling to delegate decision-making powers to a central player from another party. They suggest that the alternative contract-based approach, backed by wellinformed and transparent rules, is superior in this situation. A role remains for the finance minister even under this contract approach, but mainly to monitor and enforce the preexisting contract rather than to take a proactive role in the formation of the budget.

The new and potential EU member countries in our sample typically have multiparty coalition governments, and, therefore, the contract-based approach would appear to be the most appropriate for them. In our empirical analysis, we find that the contract approach is important. However, such an approach, formalized under medium-term budgetary frameworks (MTBFs), while potentially important, is in its early stages. As such, effective delegation to finance ministers, who maintain considerable discretionary authority, has also helped contain fiscal pressures.

\section{Budget Institutions in New and Potential EU Member States}

Based on information provided directly by the authorities and drawing on other sources (Appendix A), a quantitative index of the overall quality of budget institutions (or fiscal institutions; the two terms will be used interchangeably throughout the paper) is constructed for the ten countries: Estonia, Bulgaria, the Czech Republic, Hungary, Latvia, Lithuania, Poland, Romania, the Slovak Republic, and Slovenia. We grouped the institutional features of the budget process in three dimensions: (i) the preparation stage, when the budget is drafted; (ii) the authorization stage, in which the draft budget is approved and formalized; and (iii) the implementation phase, where the budget is executed and may be modified/amended. Institutional characteristics that promote coordinated and cohesive decision making are expected to be more conducive to fiscal discipline and therefore receive a higher score in the quantitative index used for the empirical analysis.

Preparation stage. Principles of stronger hierarchy and cooperative bargaining are applied in this phase through (i) the introduction of fiscal rules that limit deficit spending; (ii) the establishment of quantitative budgetary targets based on a macroeconomic framework from the onset of the budget formulation; and (iii) the relative dominance of the finance minister/prime minister in the budget negotiation process.

Permanent constraints on budgetary parameters, such as legal limits on the size of the budget deficits or government borrowing (variable 1 of the budget institutions index in Table A1 of Appendix A), are present in only three countries: Estonia, Latvia, and Poland. In Estonia, there are restrictions on foreign borrowing by the state (on total foreign outstanding debt and new borrowing) and on state guarantees for foreign loans. In Latvia, public borrowing is permitted only for financing capital expenditure. The Polish constitution of 1997 stipulated that the ratio of public debt to GDP must not exceed 60 percent. This rule, along with detailed regulations concerning the definition of public debt and the actions to be taken if the debt-to-GDP ratio approaches the critical value, was introduced in the organic budget law of 1999. 
With respect to variable 2 of the index, only Slovenia uses multiannual targets under an MTBF. However, five out of ten countries did substantially improve their sequence of budgetary decision making. Bulgaria and the Czech Republic moved to setting targets before the ministries develop their budget requests, and Lithuania, Poland, and Romania after receipt of the initial requests. A variety of other limits were established in the other countries.

Less variation is found in the degree of centralization of the structure of negotiations within government (variable 3 of the budget institutions index). In most countries, the ministry of finance is responsible for the compilation of the draft budget, and in all countries the finance minister conducts bilateral negotiations with the spending ministries on the budget bids. Regarding the concentration of power in reconciling disputes arising from bilateral negotiations (variable 4 of the budget institutions index), Latvia and Slovenia, where the prime minister can overrule cabinet decisions, have the most centralized structure. Lithuania, since 1999, and Poland present a more decentralized system, with the whole cabinet involved in the reconciliation process.

Authorization stage. This phase focuses on (i) explicit limits on the scope of amendments; (ii) the sequence of decision making in the legislative budget process; (iii) the relative power of the executive and parliament; and (iv) the role of the president.

In Estonia, Lithuania, and Slovenia, amendments to the budget for higher expenditure have to be offset by specific sources of financing, so as to leave the overall budget target unchanged (variable 5 of the index). Poland and Bulgaria introduced formal limits on the scope of the legislature to amend the government budget in 1998 and 2003, respectively. These constraints help reduce the common-pool problem by forcing the legislators to recognize the trade-offs between projects.

Regarding the sequence of decision making during the parliamentary budget deliberation (variable 6 of the budget institutions index), only in the Czech Republic does the budget committee initially review the draft budget; at the end of the general debate, the parliament decides on the limits to the total revenue, expenditure, and deficit. These limits cannot be changed in the subsequent readings. In most countries, the parliament takes a vote on budget aggregates at the end of the legislative procedures.

With respect to the relative power of the executive and the parliament during the deliberation of the budget (variable 7 of the budget institutions index), institutional arrangements that favor the executive when conflicts arise between it and the parliament are considered more conducive to fiscal discipline. Among the ten countries, only Poland currently contemplates the possibility of (i) calling for a vote of confidence by the government in connection with the vote on the budget; (ii) using the draft budget as the provisional budget if parliament has not adopted a budget before the start of the fiscal year; and (iii) dissolving the parliament if it fails to approve the budget in due time. In the Czech Republic, in 2001 the rules were diluted in the event a draft budget was not approved on time. The Estonian position improved in this area in 2003, when the possibility of the government's calling for a vote of confidence was introduced. 
With the exception of Hungary, Slovenia, and, more recently, Poland, the president has had some form of power in the budget process (variable 8 of the budget institutions index). The index presumes that when the president is permitted veto power, this authority will be exercised in pursuit of his/her own policy agenda, creating a more fragmented process and one less conducive to fiscal discipline.

Implementation stage. In this stage, the degree of firmness in the execution of the budget is considered (variables 9, 10, and 11 of the budget institutions index ), together with the procedures governing fiscal adjustments to unforeseen revenue shortfalls or unexpected overspending (variable 12 of the budget institutions index). The Hungarian position, already weak in this area, deteriorated in 2002 (Figure 3), as an amendment to the organic budget law was introduced that allowed considerable leeway in undertaking additional spending without supplementary appropriations and parliamentary approval. This change meant that the government could, to a certain extent, modify the budget parameters, and the agreements made in the budget planning and Figure 3. Hungary: Budget Institutions and Fiscal Performance, 1997-2003

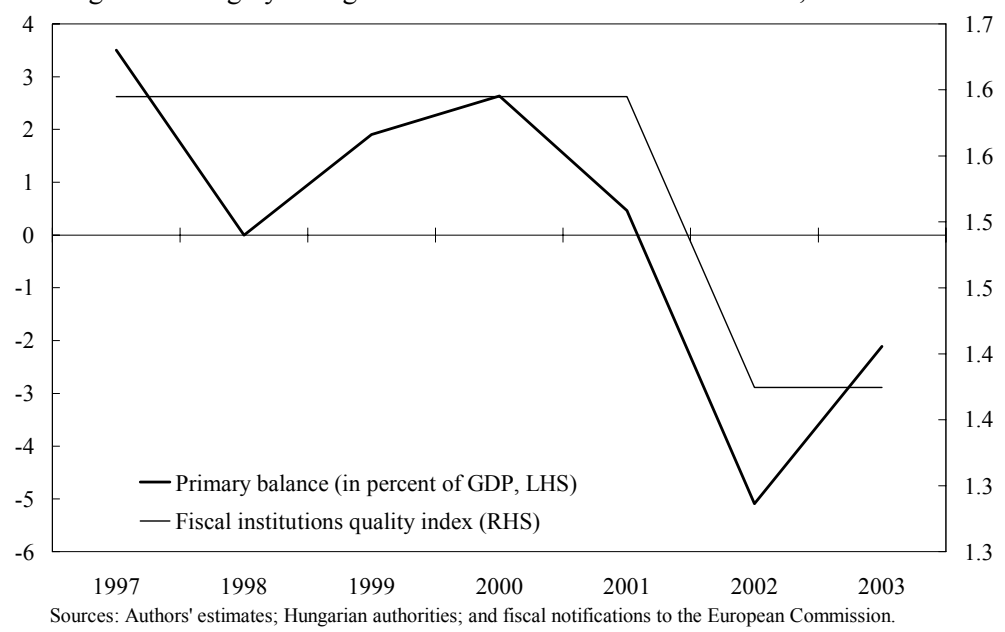
authorization phases could be undermined and the parliamentary authorization function weakened. As a consequence, the budget lost some of its commitment function, since a hard constraint was not imposed. The Czech Republic improved substantially in this dimension when it included in the 2000 budget law a formal rule that higher expenditure must be compensated for by decreasing other spending. However, the position worsened in 2001, when unused funds were allowed to be carried into the following year. Finally, in reaction to negative fiscal shocks, in four out of ten countries (Bulgaria, Estonia, Latvia, and Lithuania), the finance minister has been granted the authority to block expenditures if unforeseen revenue shortfalls or overspending occur. In the remaining countries, the cabinet, instead of the finance minister, can block expenditure without parliamentary approval.

Overall, Estonia and Slovenia stand out as countries that have done consistently well. Poland has considerably improved its position over this period. In contrast, the Hungarian position, already low, deteriorated. Table 4 shows the ranking of the ten countries for 1997 and 2003.

\section{BENCHMARK RESUltS}

The goal in this section and the next is to explain the short-term dynamics of the primary budget balance, i.e., the balance most under the control of the national authorities, thus 
excluding the costs that arise on account of relatively inflexible debt repayment. We pool the observations from the ten countries over the seven years, 1997 through 2003. The following empirical specification is used:

$$
y_{i t}=\alpha+v_{i}+\beta_{t} u_{t}+\delta x_{i t}+\phi w_{i t}+\gamma s_{i t}+\varepsilon_{i t},
$$

where $y_{i t}$ is the fiscal primary balance in country $i$ and year $t$; $v_{i}$ is a set of unchanging countryspecific effects (proxied by country dummies); and $u_{t}$ are effects common to all countries in period $t$ (time dummies). The three groups of time-varying explanatory variables are $x_{i t}$, the economic control variables; $\mathrm{w}_{i t}$, the political control variables; and $s_{i t}$, the fiscal institutions index.

In persuasively establishing the relationships outlined in equation (1), three econometric problems arise. First - and the most intractable of these - is the possibility that budget outcomes influence the evolution of fiscal institutions, rather than the other way around, as presumed. While the problem is widely recognized, it has not really been resolved, since identifying the exogenous component of fiscal institutions is hard. Alesina and Perotti (1999), Stein, Talvi, and Grisanti (1999), Knight and Levinson (2000), and Perotti and Kontopoulos (2002) discuss the difficulties in dealing with this problem of reverse causality. Identifying an "instrument," or a variable that influences the fiscal institutions but is not itself influenced by budgetary outcomes, is a hurdle that no one has yet crossed. Acemoglu (2005) is generally pessimistic about the possibility of identifying causal relationships in comparative political economy and argues that robust noncausal relationships nevertheless are of value to advancement in theoretical analysis and policymaking. The working assumption in the earlier papers, which we maintain, has been that budget performance cannot quickly feed back into alteration of budget institutions since these are costly to change. We do report results of a statistical (Arellano-Bond) procedure, which deals with the problem but cannot be regarded as conclusive.

Second, and related, is the possibility of "omitted variables." These variables, although explaining the evolution of budget outcomes, because they are omitted, their effects are incorrectly attributed to the included variables, leading, in particular, to an overstatement of the fiscal institutions effect. A partial solution to this problem is disregarding variations across countries and analyzing only the variations within a country. Doing so, in effect, eliminates $v_{i}$, which encompass a variety of country effects that may influence budget deficits but may not be observed by the econometrician. By thus focusing on variations within a country over time, the problem of omitted variables is alleviated but not eliminated. Most studies have not been able to pursue this approach either because budget institutions do not move much over time or because these movements are difficult to measure. Where it is implemented, Knight and Levinson (2000) suggest, the results are typically different from those obtained in crosscountry analysis, indicating that the problem of omitted variables is relevant. Since our data permit us to do so, the within-country analysis forms our benchmark. 
Third, and paradoxically flowing from the solution to the second problem, because some of the unchanging country effects are of analytical interest, sweeping them away only by considering changes within a country throws out important information. A partial solution to this problem has been proposed by Blanchard and Wolfers (2000). In effect, it allows the analyst to ask if the reactions to the time-varying variables are conditioned by the unchanging country characteristics of interest, as described in Box 2.

Appendix B provides details of the explanatory variables used and their data sources. Tables 2 and 3 summarize the means and correlations, respectively, of the explanatory variables. These show that, even within this relatively homogenous group, considerable heterogeneity exists.

Since we are working with only ten countries, the cross-country regressions are only briefly presented (in Table 5) to contrast the findings with the subsequent results. Among the economic conditioning variables, a higher public debt-to-GDP ratio is associated with a larger primary surplus (or smaller deficit) and is significant in some specifications, suggesting greater fiscal effort when debt payments increase. Of the four variables representing democratic practice - fragmentation of the government coalition and the three ideology variables - only the nationalism variable shows some modest significance in the cross section, with a more nationalistic ideology tending to reduce the budget surplus. Among the longer-term determinants of budgetary performance, the district magnitude shows the most action, as a larger district magnitude results in a smaller long-term surplus. Note that here, and in the rest of the paper, we use the log of the district magnitude as the explanatory variable to limit the influence of Slovak Republic, which has an especially large district magnitude. An IMFsupported program tends to be associated with a larger primary surplus. And, once we control for an IMF-supported program, there is some hint in the cross section that better budgetary institutions also help increase the primary surplus. These results are in line with the findings of Gleich (2003) and Yläoutine (2004).

When we move from the cross-sectional to the within-country analysis in Table 6, we have, in principle, seven observations for each of the ten countries for a potential total of 70 observations. However, we lose five observations (1997 for Lithuania, 1997 and 1998 for Latvia, and 1997 and 1998 for the Slovak Republic) because the ideological orientation of some of the political parties in the early years could not be identified. Also, we drop two observations (Bulgaria and Romania in 1997, when they experienced very high inflation). Thus, we work throughout with 63 observations. Throughout, by including country fixed effects, we are, in effect, seeking to explain deviations from the country mean. We also include year dummies to control for common shocks.

\section{A. Economic Influences}

As in the previous section, we begin with standard economic influences on the budget deficit (Table 6). Briefly, a higher debt level apparently induces greater fiscal effort, increasing the primary balance. However, while the sign on this variable is always positive, it is only sometimes statistically significant at conventional levels. The unemployment rate, which is more often close to statistical significance, has a negative sign, implying that an increase in the 
unemployment rate reduces the primary surplus (increases the deficit). A higher inflation rate is associated with a larger primary surplus, as if inflation reduces the real value of expenditures without compromising tax receipts. This result is consistent with that of Perotti and Kontopoulos (2002), although their finding is supported by a higher degree of statistical significance. Finally, country openness to external trade, though not significant on its own, is typically solidly significant when other conditioning variables are included, implying that countries that are more open also tend to greater fiscal conservatism. However, as we discuss below, and as is the case with the other economic variables, the significance tends to fall when pitted against the political variables, especially in the nonlinear regressions.

With these controls in place, we add our overall index of the quality of budgetary institutions to the explanation of the primary balance. The results suggest that stronger budgetary institutions are associated with a larger primary surplus (or smaller deficit). The coefficient is significant at the conventional 5 percent level of significance. A movement of the index from the $25^{\text {th }}$ percentile to the median results in an improvement of about 2 percentage points of GDP.

Before moving on to assess the role of politics on budgetary outcomes, we also examine two external anchors: membership in the European Union (EU) and an IMF-supported program. EU membership is, in fact, a misnomer since we time the EU dummy to take the value 1 from the year in which negotiations for EU entry were initiated. The premise is that the discipline required for entry into the EU and, subsequently, for euro adoption creates an anchor that reduces the fiscal deficit. The results indicate otherwise. The sign on the EU dummy is negative, showing, if anything, that the prospect of EU entry raises the deficit, though the effect is not statistically significant. We do not probe this issue in greater detail but presume that two opposing forces are working against each other: a disciplining effect counteracted by increased expenditures in response to new requirements for EU entry. Similarly, the IMFsupported program dummy is also not significant. As noted above in the cross-section results, an IMF-supported program was associated with smaller deficits. The fact that this is no longer the case in a "within" regression suggests that unobserved country factors lead to both an IMFsupported program and to smaller deficits. Once these unobserved factors are controlled for through country dummies, the direct influence of an IMF-supported program disappears.

\section{B. Political Influences}

We focus in this section on the time-varying political variables. These are of the "practice of democracy" variety rather than structural or constitutional variables, which are considered via the nonlinear estimation in the next section. In our taxonomy, voter participation also represents democratic practice, but because it displays only modest changes over time, we treat it in the next section as a time-invariant influence.

When considered one at a time, the political variables do not show much action (columns 1-4). When the three ideological variables are put together (column 5), their significance increases, though it is not especially high. The statistical significance of all variables increases sharply in column (6) when we place coalitional fragmentation alongside the three ideology variables. Thus, the findings have a few methodological implications. Fragmentation and ideology need 
to be examined together; also ideology is not unidimensional; rather, it is multifaceted. Considering these as a package provides stronger results, consistent with priors that have long existed in the literature. Since a larger number on the fragmentation variable (the Herfindahl index derived from the shares of the coalitional partners) indicates less fragmentation, the positive sign on the coefficient indicates a larger surplus with reduced fragmentation. The ideology variables indicate that a coalition that leans to the right, that is not highly nationalist, and that favors centralization of public finances is likely to deliver a conservative budget. In the specific case of our sample, it appears that leftist coalitions have been less fragmented, and some rightist coalitions have also had nationalistic tendencies. Only when these dimensions are simultaneously considered do the results show through.

\section{Economics Versus Politics}

We bring together the findings in Table 8. As noted in the introduction, a concern with this exercise is the robustness of the findings. We address, first, the robustness issue through alternative estimation procedures and a search for outliers. This leads to a discussion of the substantive conclusions. Column 1 presents the results of the random-effects estimation, which uses the cross-country and within-country variations. The conditions required for the validity of these estimates are stringent; in particular, the possibility that the omitted variables, relegated to the error term, are correlated with the included variables raises the concern that the coefficient estimates may be biased. A comparison with the fixed-effects model (columns 2 and 3), which uses only the within-country variation, suggests that the correlation with omitted variables may not be serious. ${ }^{3}$ One variable for which the coefficient changes significantly is lagged debt. The implication is that, across countries, higher debt induces greater fiscal conservatism; however, the same effect is not observed within a country over time. The statistical reason for this difference is that as debt levels vary little within a country relative to the cross-country variation (see Table 3 ), the effects of the within-country movements are difficult to identify precisely.

While our basic approach to dealing with omitted variables is through the use of country-fixed effects, we also examine if the errors were serially correlated and the lagged dependent variable was picking up additional time-varying omitted effects. The Lagrange multiplier test for serial correlation in residuals, following Baltagi (2005), suggests no serial correlation. Recognizing that this test is only approximate for unbalanced panels, we examine the possibility of dynamics through two different estimation approaches. The Arellano-Bond estimator, which, in principle, deals also with the possibility of reverse causality from budget outcomes to fiscal institutions, allows for the possibility of persistence in budget deficits (Table 8 , column 4). However, because this estimator performs well for large samples, which is not exactly our case, we also use the Kiviet bias adjustment, which works better for unbalanced panels with a small number of units (Table 8, column 5). Given the already small size of the sample, the drop in sample size when using lagged values cautions against a heavy reliance on

${ }^{3}$ Formally, a Hausman test does not reject the random-effects estimates. 
these results. However, the consistency of the results is reassuring. In particular, the lagged dependent variable is not statistically significant. In the rest of this paper, therefore, we use as a benchmark the fixed-effects, or within-country, estimates without the lagged dependent and debt variables, as in column (5) of Table 8.

Another relevant concern is the robustness of the results to possible outliers. In particular, because of the large changes in fiscal institutions in Poland and Romania, and the small sample, the question arises whether the results are driven by these countries. We followed Milesi-Ferretti, Perotti, and Rostagno (2002) and excluded one country at a time to test for the possibility of "influential" countries. However, the relevance of the fiscal institutions index does not appear to be driven by any single country. ${ }^{4}$

Substantively, when we put the economic conditioning variables alongside the political variables, politics seems to win (Table 9). In general, the strength of the economic variables declines, though their signs remain as before. Among the political variables, fragmentation becomes less significant, but it retains its expected positive sign. The two political variables that remain most clearly significant are the measures of left-right and nationalist ideology. Inclusion of the EU dummy, the IMF dummy, and the timing of elections does not change the results.

Once more, the overall index of budgetary institutions is highly significant when added to this specification, which includes the economic and political conditioning variables. Thus, while politics has a strong influence on the budget, discipline appears to be possible through the checks and balances of budgetary processes and institutions. This, then, is our principal finding, one that is confirmed in the more refined specifications discussed below.

\section{The Role OF Deeper Determinants: Time-InVARIAnt FaCtors}

There remains the possibility that the political determinants of budgetary performance, as well as the restraints exercised through sound budgetary institutions, are mainly a reflection of deeper underlying variables. Because these deeper determinants typically change very little over time (and, in our sample, do not change at all), it has become customary to assess their influence through the reaction they induce to shocks. Blanchard and Wolfers (2000) have analyzed two types of shocks: country-specific shocks (represented by time-varying country variables) and common shocks (represented by time dummies). The shocks are interacted with the time-invariant variables, and the influence of the latter is assessed by isolating their effects through a nonlinear regression (Box 2). In essence, as Blanchard and Wolfers (2000) note, the methodology evaluates if the shocks persist longer if the deeper determinants are more salient. In a short time span, a longer persistence implies a higher average realization.

\footnotetext{
${ }^{4}$ The fiscal institutions index is significant at the 7 percent level when either Hungary and Poland is dropped and at the 5 percent level when one of the other countries or both Poland and Romania are dropped.
} 
As discussed above, the theory creates some expectations regarding the direction of influence of the time-invariant political institutions but cautions about possible ambiguities and nonlinearities. Thus, Aghion, Alesina, and Trebbi (2004) argue that greater fractionalization is

\section{Box 2: Shocks and Institutions}

Blanchard and Wolfers (2000) sought to disentangle the influence of economic shocks (changes in oil prices and shifts in productivity trends) from that of sluggish labor market institutions on the evolution of unemployment. By examining the changes in the variables of interest within a country over time, they used the conventional approach to eliminate the unobserved, unchanging country influences, the so-called fixed effects (since the failure to do so creates the risk that the influence of those unobserved effects will be incorrectly attributed to the variable of interest to them). But since doing so also eliminates information on the unchanging labor market institutional variables of interest, they proposed estimating an equation of the following form:

$$
y_{i t}=\alpha+\left[1+\lambda\left(z_{i}-\bar{z}\right)\right]\left(\beta u_{t}+\delta x_{i t}\right)+\gamma s_{i t}+\phi w_{i t}+\left(v_{i}+\eta z_{i}\right)+\varepsilon_{i t} .
$$

In effect, this procedure (with coefficient estimates obtained by nonlinear least squares) tests if time-invariant variables, such as labor market or political institutions, shape different responses to common and country-specific economic and political events (for recent applications, see Persson, 2002, and Milesi-Ferretti, Perotti, and Rostagno, 2002). Country-

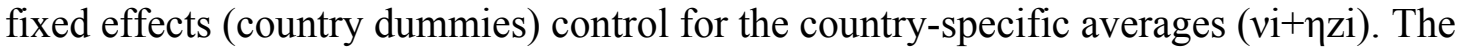
crucial new parameter is $\lambda$. The formulation postulates a common response, $\beta$ ut, to common

shocks, ut. In turn, however, the common response is shaped by the term $\lambda\left(z_{i}-\bar{z}\right)$, reflecting the influence of country institutions zi (e.g., the district magnitude). Because zi is measured as a deviation from the mean across countries, $\beta u t$ is the measured response in the sample when the zi is at the mean of the sample. In Tables 10-11, we allow also for zi's to interact with country-specific shocks, the variables xit, again, following Blanchard and Wolfers (2000). In Table 11, the response to fiscal institutions, ${ }_{i t}$, is also mediated through the unchanging political environment.

Notice that the specification implies that the same coefficient, $\lambda$, conditions all the shocks. In principle, it is possible to allow differential responses. However, the number of parameters quickly explodes. Blanchard (2005), in reviewing the evolution of recent research, recognizes the importance of exploring a variety of interactive effects but cautions that the differential effects may be difficult to identify. In the context of testing for the effect of central bank independence, Franzese (1999) allows for differential interactions but concludes, in that case, that the assumption of a common mediating effect is a justifiable approximation. 
divisive and leads to greater competition for resources and, hence, less fiscal discipline; however, these negative effects may be offset through the choice of political institutions. ${ }^{5}$ Similarly, greater proportionality in electoral rules is expected to lead to the formation of more diverse coalitions, which, in turn, are expected to hurt fiscal discipline. Since we control for the diversity of coalitions, the measured effect of a larger district magnitude may either be an additional influence, reflect nonlinearities, or represent inadequacies in our measure of government fragmentation. ${ }^{6}$ Finally, as Mueller and Stratmann (2003) show, when voter participation is high, pressures to meet the demands of a variety of constituencies may lead to higher public expenditures and/or lower taxes and, hence, to larger deficits.

\section{A. The Main Results}

In general, as we have cautioned, the effects of the time-invariant variables are sensitive to the specifications. Though the direction of influence is typically plausible, both the strength and statistical significance of the influence tend to be unstable. ${ }^{7}$ The results are presented in four steps, each step testing the robustness of the findings while also addressing issues of substantive interest. In the first step (columns 1-3 of Table 10), we allow the possibility that the time-invariant variables mediate domestic shocks (developments in inflation, employment, and the trade-to-GDP ratio) and the common shocks (represented by time dummies). Greater ethnic diversity appears to amplify adverse shocks, i.e., an adverse shock to the budget has a bigger impact under conditions of greater diversity. The sign of this coefficient, however, is not significant in this specification. A larger district magnitude and greater voter turnout also amplify adverse shocks, and, in these cases, the statistical significance varies between 5 and 10 percent range.

${ }^{5}$ As noted, the measure of language fractionalization is virtually the same as that of ethnic fractionalization. Though religious fractionalization is also highly correlated with ethnic fractionalization, it gives quite different results, often appearing with a positive sign, suggesting that more fractionalization is associated with greater budget discipline. Importantly, the variables of interest to us, the quality of budgetary institutions and the time-varying political variables, remain significant and important even when religious fractionalization is included.

${ }^{6}$ Also, we use here the conventional measure of the number of representatives elected from each district. Milesi-Ferretti, Perotti, and Rostagno (2002) propose a "standardized" measure of district magnitude, which corrects for a threshold number of votes required to gain representation and, hence, reduces somewhat the size of the district magnitude where the thresholds apply. The standardized measure gives less precise results.

${ }^{7}$ The greater instability in the coefficient on the time-invariant variables, compared with the other political controls we have used so far, is to be expected since we have a sample of only ten countries and changes in specification are more likely to influence the time-invariant variables. 
In the second step (columns 4-6, Table 10), we add the lagged debt-to-GDP ratio as a timeinvariant variable. The results above showed that the time variation in the debt-to-GDP ratio did not have a material bearing on the movements in the primary surplus. This reflects, in part, the fact that much of the sample variation in the debt-to-GDP ratio is across countries rather than within countries over the short time period covered. Thus, for such short periods, we ask if the level of debt conditions the responses to shocks. The answer is yes, but in a manner that goes against recent evidence of mean reversion. Positive shocks to the budget are muted (negative shocks are amplified) in countries with heavier debt ratios. At least in the short run, then, the finding suggests that a country experiencing an improving budgetary position will choose to be less conservative if it has a higher debt burden. This finding is consistent with the Velasco (1999) finding that debt levels may have to cross a threshold before they induce policymakers to tighten their fiscal belts (see Box 1). Thus, while the intertemporal budget constraint would need to be eventually satisfied (as Bohn 1998 suggests), evidently the relatively low debt levels in some of the countries and the relative ease of market financing where debt levels are higher implies that the stock of debt need not constrain short-term budgetary priorities. Notice also that, with the introduction of the debt ratio as a conditioning variable, most results are strengthened.

Moreover, the role of contemporary politics remains salient. Indeed, if anything, with the inclusion of the time-invariant variables, the four contemporary political variables - coalitional fragmentation and the three ideological variables - are now all highly significant. The implication is that contemporary politics is not entirely driven by deeper determinants. Rather, short-term forces can generate political configurations that can move politics against the direction dictated by the longer-term forces, thereby aggravating or mitigating the role of divisive forces.

Finally, the budgetary institutions index remains strongly significant. Relative to earlier estimates, the point estimate is now somewhat lower, at about 51/2-6; this suggests that a move in institutional quality from the $25^{\text {th }}$ to the $50^{\text {th }}$ percentile leads to an improvement in the primary surplus of about $1 \frac{1}{2}$ percent of GDP.

In the third and fourth steps (Table 11), we allow for the possibility that shocks to fiscal institutions are also conditioned by the time-invariant variables. In columns $1-3$, we do not include the debt-to-GDP ratio, and in columns 4-6 we do. The coefficient on the fiscal institutions index should now be interpreted as the response of the primary budget to fiscal institutions at the mean value of the time-invariant influences (since those variables are entered into the regressions as deviations from their sample means). Thus, in this representation, each country has its own response to improvements in fiscal institutions, depending on the specific values of the time-invariant variables. Estimates show that, though varying in strength, stronger fiscal institutions help everywhere, expect possibly in the Slovak Republic, with a large district magnitude and high voter participation. Clearly, these results reflect the imposition of a linear conditioning response, which forces a structure that may not be tenable. Since that was not the 
main purpose of this paper, we did not pursue nonlinear possibilities in any depth, leaving it to be examined in the context of a larger sample. ${ }^{8}$

\section{B. Model Predictions}

How well do these models perform? We present two examples. Figure 4 shows the actual and model-predicted values of the budget balance for Poland and Hungary. The predictions match the actual values rather well, both in absolute magnitudes and changes in direction. For Poland, the early improvement in budget balance reflects, in part, the improvement in the domestic fiscal institutions. However, budget performance deteriorated thereafter. Mechanically, this reflects a decline in the inflation rate, which results in a drop in the fiscal balance. The interpretation is that some part of the apparent strength in the fiscal balance was achieved by higher inflation, and the underlying weaknesses were revealed once the inflation rate fell. Thus, while improved fiscal institutions helped, the endemic problems require stronger solutions. In Hungary, the worsening prediction of the budget balance in the last two years of the sample period reflects the worsening institutions.

Figure 4. Primary Balance and Fitted Values (Nonlinear least squares estimates, in percent of GDP)
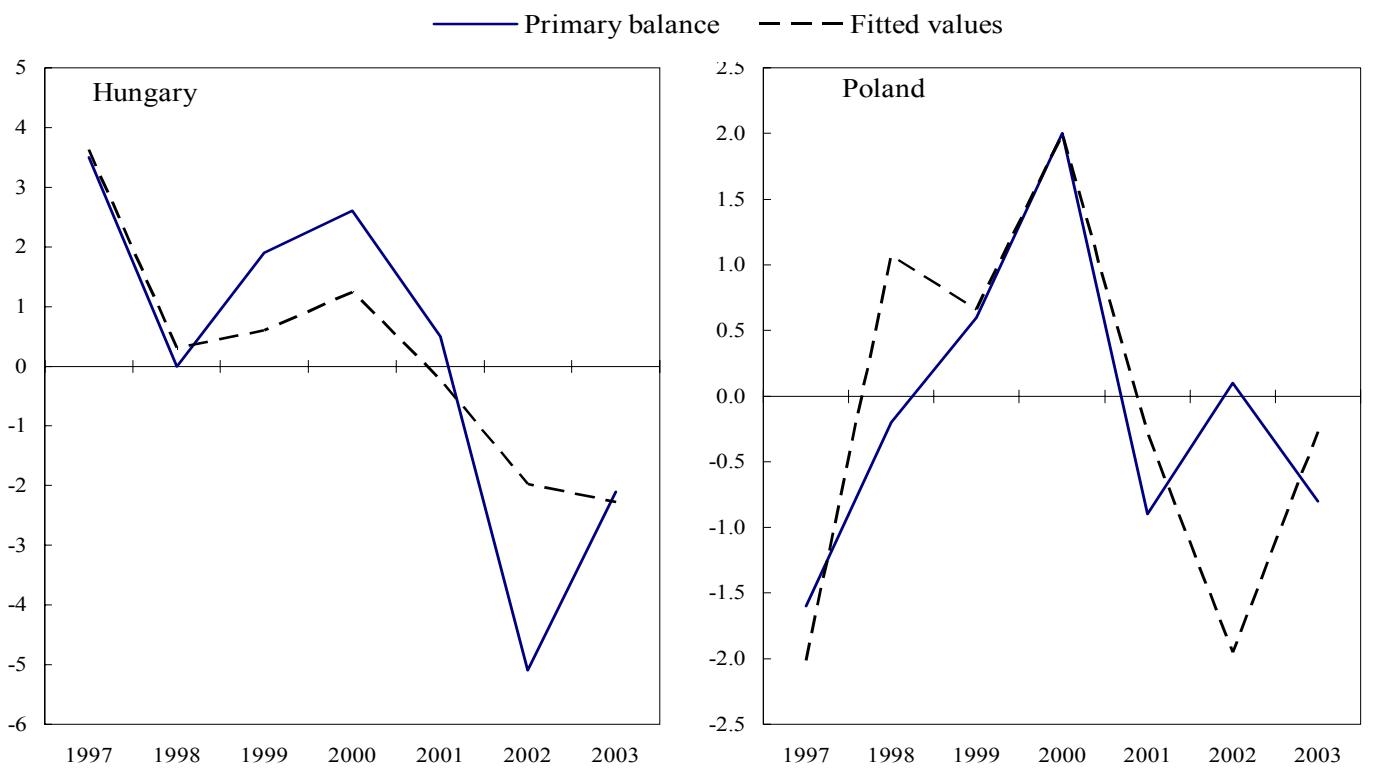

Sources: Authors' estimates; and fiscal notifications to European Commision.

${ }^{8}$ Following a suggestion by Hallerberger and Marier (2004), we examined the possibility of piecewise linearity for district magnitude: the results suggest that an initial rise in district magnitude may help fiscal discipline before the influence turns negative at a district magnitude of about 20. 


\section{Components of the Budget Institutions Index}

Finally, we examine if the three components of the budget institutions index have a differential impact on performance (Table 12). While each component appears to have a strong and independent force, the implementation stage appears to be the most relevant. The implication, therefore, is that, while the rules in the preparation phase and the bargaining that goes on during the authorization stage restrain fiscal irresponsibility, the greater danger arises from the budget implementation; this, in turn, implies that checks are needed to ensure that the efforts of the first two phases are not undone. The political fragmentation and ideological variables remain strong influences. While the three time-invariant variables are important, there is a difference across the stages of some interest. In the two earlier phases of preparation and legal authorization, voter participation has a strong influence; however, in the final implementation phase, when, presumably, the actions are less visible to voters, the degree of voter participation in the democratic process has a smaller influence.

Column (4) examines if the three different phases that we identify are substitutes for each other. In other words, if any one of the phases is weakly developed, is it possible to compensate for that in another phase with stronger checks and balances? To examine this question, we created a new index that took the lowest of the three values from the three phases for each country in each year. The goal was to assess if the weakest phase could undermine fiscal responsibility. The results suggest that the phases are not substitutes and that weak links in the budget preparation, authorization, and implementation phases can hurt fiscal discipline; therefore, policy attention to all phases is required.

Columns (5) and (6) test for the differences between the delegation and contract-based approaches. The indices for the delegation and contract-based approaches were obtained by summing up items of the fiscal institutions index that are relevant in those settings. The delegation-approach index was formed by items 2-7, and 9-12, while the contract-based index by items 1, 5-7, and 9-11 (Appendix A, Table A1). The results suggest that both are statistically important. This appears to go against the Hallerberg and von Hagen (1999) hypothesis that the contract-based approach is most relevant for multiparty coalitions because the finance minister cannot be trusted fully by coalitional partners to act on their behalf and, hence, delegation may prove ineffective. However, these authors also find that when budgetary institutions are "young," the delegation and contract indices are correlated and both aspects are salient. Their results for the EU-15 show that, between 1981 and 1994, the delegation approach was statistically significant in countries where it was expected to work and in the "contractbased" states where it was not. Only since 1998 has the divergence between the two approaches become evident, with the delegation approach significant only in the "delegation" states; similarly, the contract-based approach is significant only in the "contract" states (Hallerberg, Strauch, and von Hagen, 2004). It is possible, then, that such divergence will appear in central and eastern Europe. However, Poterba and von Hagen (1999, p. 4) offer the following caution: "The empirical evidence suggesting that institutions matter is stronger than the evidence on the mechanisms by which these institutions matter." Thus, moving from these results to specific policy advice will ultimately depend on a more careful consideration of individual country circumstances. 


\section{DIFFERENTIATING THE EFFECTS ON EXPENDITURES AND REVENUES}

Finally, we examine if fiscal institutions operate through the expenditure or revenue side of the budget. We estimate expenditure and revenue equations, jointly using the seemingly unrelated regressions methodology to gain efficiency. These results should be interpreted with caution, because the data available for revenue and expenditure (from the World Economic Outlook database) are not always consistent with the primary balance data used in the previous analysis (European System of Accounts '95 data from the countries' fiscal notifications to the European Commission) and are affected by breaks in the series.

In Table 13, we report results obtained by jointly estimating the expenditure and revenue equations (see Box 3). Following Persson (2002), we use in this analysis a more direct measure of "observable" shocks, as distinct from time dummies used earlier to proxy "unobservable" shocks. We use three alternative shocks: GDP growth in the EU-15, oil price movements, and the average of the lagged primary balances in Germany and France.

\section{Box 3: Observable Shocks, Institutions, and the Evolution of Expenditures and Revenues}

The expenditure and revenue equations are estimated jointly through the seemingly unrelated regressions procedure (to allow for correlations in error terms of these equations), enhancing the efficiency of the estimates. For each equation, the following parametrization is used:

$$
y_{i t}=\alpha+\left(\beta+\phi z_{i}\right) u_{t}+\delta x_{i t}+\phi w_{i t}+\gamma s_{i t}+\left(v_{i}+\eta z_{i}\right)+\varepsilon_{i t},
$$

where $y_{i t}$ represents either expenditure or revenues at time $t$ in country $i$. As above, countryfixed effects eliminate the unchanging country features, $\left(v_{i}+\eta z_{i}\right)$. The movement of observed variables proxies for common shocks, $u_{t}$. In addition to the oil prices used by Persson (2002), we also use growth in the EU-15 and the primary budget balance in France and Germany. The response to these shocks is shaped by the time-variant variables, $z_{i}$.

Not surprisingly, it is not easy to explain movements in the tax-to-GDP ratio (Table 13). ${ }^{9}$ Political economy models speak less to the determinants of taxation than they do the common-

${ }^{9}$ Here, as elsewhere, we explored if the "output gap," the difference between actual and potential output, influenced the tax-to-GDP ratio. Given the difficulties in constructing such a measure from a short time series for countries that have emerged from transition only in the mid-1990s, it is not surprising that the measured output gap was not associated with taxes, or with expenditures or budget deficits. 
pool problems relating to expenditures (see also Perotti and Kontopoulos 2002). Inertia in tax receipts, reflected in the significant coefficient on the lagged tax variable, explains a part of the movement. Interestingly, external shocks play a more salient role in the evolution of tax receipts. Of these, a rise in oil prices is most consistently related to higher tax receipts, possibly due to import and excise duties. As with expenditures, revenues do not keep pace with externally induced growth. Also, a large surplus in Germany and France is associated with a lower tax-to-GDP ratio; hence, if a discipline effect exists, it is mainly through the expenditure side and the gains are partially relinquished on the tax receipts.

Finally, do the external shocks interact with the time-invariant variables, and, if they do, is the role of fiscal institutions altered? The answer to the latter question is no: the role of fiscal institutions remains strong and robust on the expenditure side (Table 14). With respect to the role of the interactions, the results are mixed and suggest that the different shocks work through different time-invariant variables. A larger district magnitude is associated (weakly) with higher expenditures when EU growth increases, i.e., countries with larger district magnitude tend to raise their expenditures to a greater extent than those with smaller district magnitudes. Larger district magnitudes also are associated with lower tax receipts when oil prices rise. In contrast, a larger voter turnout appears to operate through higher expenditures when there is an oil price shock.

\section{Conclusions}

Politics has a crucial influence on budget outcomes - a widely accepted conclusion, which we confirm for a group of new and potential members of the European Union over the period 1997-2003. We find, moreover, that politics works not only through long-term determinants but also more evidently through the operation of contemporary democratic practice. In other words, while structural and historical features of an economy influence the claim on budgetary resources and, hence, the degree of budgetary discipline, they do not fully predetermine the workings of contemporary politics; these workings, therefore, exercise an independent influence on budgets. Also, we find that contemporary politics itself is not straightforward to characterize and is best represented by a vector of attributes. In the context of this paper, the combination of government fragmentation in the ruling coalition, the ideological predispositions along different dimensions (the traditional left-right divide, nationalism, and the emphasis on decentralization of government), and the degree of voter participation contribute to budgetary outcomes. We note, in particular, that government fragmentation will often not reveal itself to be important unless juxtaposed with ideological orientation. The results on voter participation, supporting earlier findings of Mueller and Stratmann (2003), are troubling and suggest that greater democratic participation is accommodated by increased budgetary indiscipline.

If politics is so influential — and, particularly if politics is set on an unrelenting long-term historical course - then is budget discipline a hopeless cause? The answer, apparently, is nohope is not lost. For a measure of the quality of fiscal institutions, intended to capture checks and balances through hierarchical rules and collegiality, we find that a higher quality of institutions has a material bearing on the budgetary discipline. This discipline, apparently, acts 
through constraints on expenditures, which is where the scope for indiscipline is greatest, because politicians, while benefiting themselves and their constituents from additional expenditures, do not fully bear the costs of those additional expenditures.

The question of policy interest then is, What are the determinants of good fiscal institutions? This is not a question we tackle. Clearly, in the context of the countries we examine, there was a window of opportunity during the transition from centrally planned to market economies when the old political constraints were (partially) broken down, creating the possibility of a wide-ranging set of reforms. Enhancing the quality of fiscal institutions was apparently part of the agenda of reformers during this period. However, as we document, progress was not uniform, and there were slippages.

This leads to the further question: Is the necessary institutional engineering feasible elsewhere or, indeed, even in these same countries as a new politics takes over? This is, of course, a difficult question. The answer, to the extent our paper hints at one, is yes, if the politics behave. Fiscal institutions are somewhat correlated with both the practice of contemporary politics and long-term structural features. This is seen in our finding that the coefficient on budget institutions' quality, though remaining highly significant, is whittled down as we introduce these political determinants of budgetary outcomes. In part, then, the quality of budgetary institutions is a reflection of a fiscally conservative political system. To the extent that political forces turn away from fiscal conservatism, the likelihood of fiscal institutions reforms will decline. Thus, although our principal message is that of hope-because, empirically, long-term determinants do not exercise the tyranny that had been feared-the tussle between the forces supporting sound institutions and the politics of claims on budgetary resources will continue. 


\section{REFERENCES}

Acemoglu, D., 2005, “Constitutions, Politics, and Economics,” Journal of Economic Literature, Vol. 43, No. 4, pp. 1025-1048.

Aghion, P., A. Alesina, and F. Trebbi, 2004, “Endogenous Political Institutions," Quarterly Journal of Economics, Vol. 119 (May), pp. 565-612.

Alesina, A., R. Hausmann, R. Hommes, and E. Stein, 1999, "Budget Institutions and Fiscal Performance in Latin America," Journal of Development Economics, Vol. 59, No. 2, pp. 253-273.

Alesina, A., and R. Perotti, 1999, "Budget Deficits and Budget Institutions," in Fiscal Institutions and Fiscal Performance, ed. by J. Poterba and J. von Hagen (Chicago: University of Chicago Press).

Allen R., and D. Tommasi, 2001, Managing Public Expenditure: A Reference Book for Transition Countries (Paris: OECD).

Alt, J., and R. Lowry, 1994, "Divided Government, Fiscal Institutions, and Budget Deficits: Evidence from the States," American Political Science Review, Vol. 88, pp. 811-828.

Annett, A., J. Decressin, and M. Deppler, 2005, "Reforming the Stability and Growth Pact, IMF Policy Discussion Paper, PDP/05/2 (Washington D.C.: International Monetary Fund).

Baltagi, B. H., 2005, Econometric Analysis of Panel Data (Chichester; Hoboken, NJ: J. Wiley and Sons).

Besley, T., and A. Case, 2003, "Political Institutions and Policy Choices: Evidence from the United States," Journal of Economic Literature, Vol. 41, No. 1, pp. 7-73.

Blanchard, O., 2005, "European Unemployment: The Evolution of Facts and Ideas," Massachusetts Institute of Technology, Department of Economics, Working Paper 05/24 (Cambridge: Massachusetts).

Blanchard, O., and J. Wolfers, 2000, "The Role of Shocks and Institutions in the Rise of European Unemployment: The aggregate Evidence,” 1999 Harry Johnson Lecture, Economic Journal, Vol. 100 (March), pp. C1-33.

Benoit, K., and M. Laver, 2006, Party Policy in Modern Democracies (London: Routledge).

Bohn, H., 1998, “The Behavior of U.S. Public Debt and Deficits," Quarterly Journal of Economics, Vol. 113, pp. 949-963. 
Bruno G., 2005, "Estimation and Inference in Dynamics Unbalanced Panel Data Models with a Small Number of Individuals," Stata Journal, StataCorp LP, Vol. 5, No. 4, pp. 473500.

Cukierman, A. and M. Tomassi, 1998, "When Does It Take a Nixon to Go to China?" American Economic Review, Vol. 88, No. 1, pp. 180-197.

Eichengreen, B., R. Hausmann, J. von Hagen, 1999, "Reforming Budgetary Institutions in Latin America: The Case for a National Fiscal Council," Open Economies Review, Vol. 10, pp. 415-442.

Franzese, R., 1999, "Partially Independent Central Banks, Politically Responsive Governments, and Inflation," American Journal of Political Science, Vol. 43, No. 3, pp. 681-706.

Gleich, H., 2003, "Budget Institutions and Fiscal Performance in Central and Eastern European Countries," European Central Bank, Working Paper No. 215 (Frankfurnt, Germany: European Central Bank).

Hahm, S., M. Kamlet, and D. Mowery, "The Political Economy of Deficit Spending in Nine Industrialized Parliamentary Democracies," Comparative Political Studies, Vol. 29, No. 1, pp. 52-77.

Hallerberg, M, and P. Marier, 2004, "Executive Authority, the Personal Vote, and Budget Discipline in Latin American and Caribbean Countries," American Journal of Political Science, Vol. 48, No. 3, pp. 571-87.

Hallerberg, M., R. Strauch, and J. von Hagen, 2004, "Budgeting in Europe After Maastricht: Patterns of Reforms and Their Effectiveness," Hacienda Publica Española, No. 167, pp. 201-25.

Hallerberg, M., and J. von Hagen, 1999, "Electoral Institutions, Cabinet Negotiations, and Budget Deficits in the European Union" in Fiscal Institutions and Fiscal Performance, ed. by J. Poterba and J. von Hagen (Chicago: University of Chicago Press).

Knight, B. and A. Levinson, 2000, "Fiscal Institutions in US States," in Institutions, Politics, and Fiscal Policy, ed. By R. Strauch and J. von Hagen (Boston: Kluwer Academic Publishers).

Kontopoulos, Y., and R. Perotti, 1999, "Government Fragmentation and Fiscal Policy Outcomes: Evidence from OECD Countries," in Fiscal Institutions and Fiscal Performance, ed. by J. Poterba and J. von Hagen (Chicago: University of Chicago Press).

Lijphart, A, 1994, Electoral Systems and Party Systems (Oxford: Oxford University Press). 
Milesi-Ferretti, G.M., R. Perotti, and M. Rostagno, 2002, "Electoral Systems and Public Spending," Quarterly Journal of Economics (May), pp. 609-657.

Mueller Dennis, and Thomas Stratmann, 2003, "The economic effects of democratic participation," Journal of Public Economics, Vol. 87, Nos. 9-10, pp. 2129-2155.

Perotti, R. and Y. Kontopoulos, 2002, "Fragmented Fiscal Policy,” Journal of Public Economics, Vol. 86, pp. 191-222.

Persson, T., 2002, “Do Political Institutions Shape Economic Policy?” Econometrica, Vol. 70 (May), pp. 883-905.

_ 2004, "Consequences of Constitutions," Journal of the European Economic Association," Vol. 2, Nos. 2-3, pp. 139-161.

Persson, T., G. Roland, and G. Tabellini, 2005, "Electoral Rules and Government Spending in Parliamentary Democracies," unpublished.

Persson, T., and G. Tabellini, 2000, Political Economics: Explaining Economic Policy, (Cambridge, Massachusetts: MIT Press).

_ 2003, The Economic Effects of Constitutions, (Cambridge, Massachusetts: MIT Press).

_ 2004, "Constitutional Rules and Fiscal Policy Outcome," American Economic Review, Vol. 94 (March), pp.25-45.

Poterba, J., 1994, "State Responses to Fiscal Crises: The Effects of Budgetary Institutions and Politics," Journal of Political Economy, Vol. 102, No. 4, pp. 799-821.

_ 1996, “Do Budget Rules Work?” National Bureau of Economic Research Working Paper 5550 (Cambridge, Massachusetts).

Potter, B., and J. Diamond, 1999, Guidelines for Public Expenditure Management, (Washington D.C.: International Monetary Fund).

Roubini, N. and J. Sachs, 1989, "Government Spending and Budget Deficits in the Industrial Democracies," Economic Policy, Vol. 8, pp. 100-132.

Shepsle, K. and B. Weingast, 1981, "Political Preferences for the Pork Barrel: A Generalization,” American Journal of Political Science, Vol. 25, No. 1, pp. 96-111.

Stein, E., E. Talvi, and A. Grisanti, 1999, "Institutional Arrangements and Fiscal Performance: The Latin American Experience," in Fiscal Institutions and Fiscal Performance, ed. by J. Poterba and J. von Hagen (Chicago: University of Chicago Press). 
Velasco, A., 1999, “A Model of Endogenous Fiscal Deficits and Delayed Fiscal Reforms," in Fiscal Institutions and Fiscal Performance, ed. by J. Poterba and J. von Hagen (Chicago: University of Chicago Press).

— 2000, "Debts and Deficits With Fragmented Fiscal Policymaking," Journal of Public Economics, Vol. 76 (April), pp.105-25.

von Hagen, J., and I. Harden, 1995, "Budget Processes and Commitment to Fiscal Discipline," European Economic Review, Vol. 39 (April), pp.771-9.

Weingast, B., K. Shepsle, and C. Johnson, 1981, "The Political Economy of Benefits and Costs: A Neoclassical Approach to Distributive Politics," Journal of Political Economy, Vol. 89, pp. 642-664.

Wyplosz, C., 2005, "Fiscal Policy: Institutions versus Rules," National Institute Economic Review, Vol. 191 (January), pp. 64-78.

Yläoutinen, S., 2004, "Fiscal Frameworks in the Central and Eastern European Countries," Finnish Ministry of Finance Discussion Paper No. 72 (Ministry of Finance of Finland). 
Table 1. Data Description: Mean by Country

\begin{tabular}{lrrr}
\hline \hline Country & $\begin{array}{c}\text { Ethnic } \\
\text { fractionalization }\end{array}$ & $\begin{array}{c}\text { Average district } \\
\text { magnitude }\end{array}$ & Voter turnout \\
\hline Bulgaria & 0.40 & 7.7 & 66.9 \\
Czech Republic & 0.32 & 25.0 & 69.4 \\
Estonia & 0.51 & 9.2 & 61.5 \\
Hungary & 0.15 & 12.2 & 66.4 \\
Latvia & 0.59 & 20.0 & 76.2 \\
Lithuania & 0.32 & 35.3 & 62.1 \\
Poland & 0.12 & 16.7 & 48.7 \\
Romania & 0.31 & 7.8 & 70.7 \\
Slovak Republic & 0.25 & 150.0 & 76.6 \\
Slovenia & 0.22 & 11.0 & 76.7 \\
\hline \hline
\end{tabular}

Source: Authors' calculations. 
-32 -

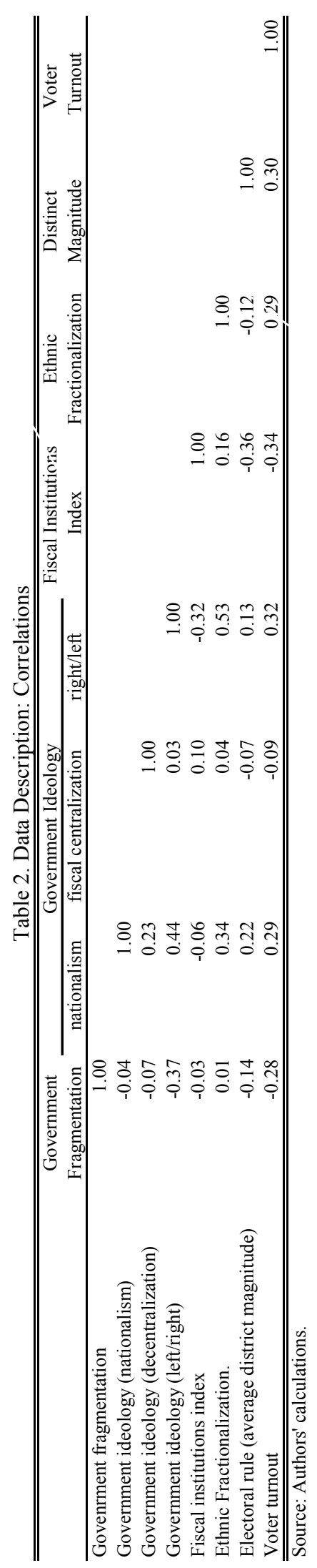


Table 3. Descriptive Statistics

\begin{tabular}{|c|c|c|c|c|c|}
\hline Variable & & Mean & Std. Dev. & Min & Max \\
\hline \multirow[t]{3}{*}{ Unemployment rate } & overall & 11.29 & 4.23 & 4.30 & 20.00 \\
\hline & between & & 4.06 & 6.16 & 18.11 \\
\hline & within & & 1.98 & 6.05 & 15.65 \\
\hline \multirow[t]{3}{*}{ Inflation } & overall & 9.17 & 11.12 & -1.20 & 59.10 \\
\hline & between & & 10.20 & 1.22 & 37.15 \\
\hline & within & & 5.75 & -12.68 & 31.12 \\
\hline \multirow[t]{3}{*}{ Openness index } & overall & 0.90 & 0.25 & 0.46 & 1.36 \\
\hline & between & & 0.25 & 0.51 & 1.24 \\
\hline & within & & 0.09 & 0.70 & 1.10 \\
\hline \multirow[t]{3}{*}{ Fiscal institutions index } & overall & 2.12 & 0.45 & 1.37 & 2.72 \\
\hline & between & & 0.45 & 1.46 & 2.63 \\
\hline & within & & 0.13 & 1.37 & 2.47 \\
\hline \multirow[t]{3}{*}{ Government fragmentation } & overall & 0.63 & 0.20 & 0.27 & 1.00 \\
\hline & between & & 0.14 & 0.42 & 0.81 \\
\hline & within & & 0.15 & 0.29 & 0.96 \\
\hline \multirow[t]{3}{*}{ Left/right } & overall & 11.11 & 3.53 & 5.81 & 17.35 \\
\hline & between & & 2.84 & 6.41 & 16.40 \\
\hline & within & & 2.32 & 5.55 & 15.95 \\
\hline \multirow[t]{3}{*}{ Nationalism } & overall & 11.44 & 3.48 & 6.80 & 17.57 \\
\hline & between & & 2.80 & 7.11 & 16.28 \\
\hline & within & & 2.37 & 6.15 & 15.28 \\
\hline \multirow[t]{3}{*}{ Fiscal centralization } & overall & 10.46 & 2.00 & 7.09 & 13.46 \\
\hline & between & & 1.28 & 8.41 & 12.92 \\
\hline & within & & 1.63 & 7.30 & 13.62 \\
\hline \multirow[t]{2}{*}{ Ethnic fractionalization } & overall & 0.31 & 0.14 & 0.12 & 0.59 \\
\hline & between & & 0.15 & 0.12 & 0.59 \\
\hline \multirow{2}{*}{$\begin{array}{l}\text { District magnitude } \\
\text { (logarithms) }\end{array}$} & overall & 2.83 & 0.81 & 2.00 & 5.00 \\
\hline & between & & 0.90 & 2.00 & 5.00 \\
\hline \multirow[t]{2}{*}{ Voter turnover } & overall & 67.00 & 8.39 & 48.70 & 76.70 \\
\hline & between & & 8.67 & 48.70 & 76.70 \\
\hline \multirow[t]{3}{*}{ Debt-to-GDP (lagged) } & overall & 33.99 & 23.34 & 5.80 & 107.50 \\
\hline & between & & 23.75 & 6.69 & 82.90 \\
\hline & within & & 5.63 & 12.80 & 58.60 \\
\hline
\end{tabular}

Source: Authors' calculations. 
Table 4. Budget Institutions Quality Index

\begin{tabular}{|c|c|c|c|c|c|c|c|c|}
\hline & \multicolumn{4}{|c|}{$\begin{array}{c}1997 \\
\text { Rank 1/ }\end{array}$} & \multicolumn{4}{|c|}{$\begin{array}{c}2003 \\
\text { Rank 1/ }\end{array}$} \\
\hline & 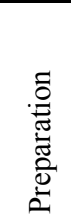 & 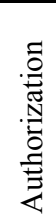 & 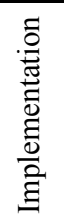 & $\begin{array}{l}\overline{\bar{\sigma}} \\
\overline{0} \\
\text { oे }\end{array}$ & 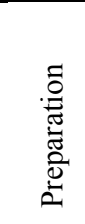 & 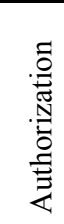 & 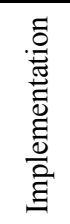 & $\begin{array}{l}\overline{\bar{\pi}} \\
\overline{0} \\
\text { ठ }\end{array}$ \\
\hline Estonia & 3 & 2 & 1 & 1 & 3 & 2 & 1 & 1 \\
\hline Poland & 4 & 7 & 5 & 6 & 3 & 1 & 4 & 1 \\
\hline Slovenia & 1 & 3 & 7 & 2 & 1 & 4 & 7 & 3 \\
\hline Latvia & 2 & 8 & 1 & 3 & 2 & 9 & 1 & 4 \\
\hline Czech Republic & 7 & 1 & 8 & 4 & 5 & 2 & 8 & 5 \\
\hline Lithuania & 7 & 4 & 1 & 5 & 5 & 5 & 5 & 6 \\
\hline Romania & 6 & 10 & 4 & 7 & 8 & 7 & 3 & 7 \\
\hline Bulgaria & 7 & 9 & 6 & 9 & 5 & 10 & 5 & 8 \\
\hline Slovak Republic & 10 & 5 & 9 & 10 & 10 & 6 & 9 & 9 \\
\hline Hungary & 4 & 6 & 10 & 8 & 8 & 7 & 10 & 10 \\
\hline
\end{tabular}

Sources: Authors' calculations; Gleich (2003); and Ylaoutinen (2004).

1/ Higher rank indicates better quality. 
Table 5. Economics, Politics, and Fiscal Performance: Evidence from Cross-Country Regressions

Primary balance-to-GDP ratio

\begin{tabular}{|c|c|c|c|c|c|c|}
\hline & (1) & (2) & (3) & (4) & $(5)$ & (6) \\
\hline Debt-to-GDP ratio & $\begin{array}{c}0.06 \\
(0.04)\end{array}$ & $\begin{array}{c}0.05 \\
(0.02)^{*}\end{array}$ & $\begin{array}{c}0.08 \\
(0.02)^{* *}\end{array}$ & & $\begin{array}{c}0.06 \\
(0.03)^{*}\end{array}$ & $\begin{array}{c}0.06 \\
(0.02)^{* *}\end{array}$ \\
\hline Unemployment rate & $\begin{array}{l}-0.07 \\
(0.23)\end{array}$ & & & & & \\
\hline Inflation & $\begin{array}{c}0.02 \\
(0.08)\end{array}$ & & & & & \\
\hline Openness index & $\begin{array}{l}-1.72 \\
(3.33)\end{array}$ & & & & & \\
\hline IMF program dummy & & $\begin{array}{c}2.79 \\
(1.33)^{*}\end{array}$ & $\begin{array}{c}3.09 \\
(1.06)^{* *}\end{array}$ & & & $\begin{array}{l}1.909 \\
(1.06)\end{array}$ \\
\hline $\begin{array}{l}\text { Government } \\
\text { fragmentation }\end{array}$ & & & & $\begin{array}{c}0.65 \\
(6.04)\end{array}$ & & \\
\hline Government ideology: & & & & & & \\
\hline Right/left & & & & $\begin{array}{c}0.27 \\
(0.32)\end{array}$ & & \\
\hline Nationalism & & & & $\begin{array}{l}-0.56 \\
(0.34)\end{array}$ & & \\
\hline Centralization & & & & $\begin{array}{c}0.51 \\
(0.61)\end{array}$ & & \\
\hline Fiscal institutions index & & & $\begin{array}{c}2.74 \\
(1.21)^{*}\end{array}$ & & & $\begin{array}{c}1.52 \\
(1.18)\end{array}$ \\
\hline Ethnic Fractionalization & & & & & $\begin{array}{c}3.37 \\
(4.34)\end{array}$ & \\
\hline District magnitude & & & & & $\begin{array}{l}-1.5 \\
(0.5)^{* *}\end{array}$ & $\begin{array}{l}-1.03 \\
(0.53)\end{array}$ \\
\hline Voter turnout & & & & & $\begin{array}{l}-0.04 \\
(0.05)\end{array}$ & \\
\hline Number of countries & 10 & 10 & 10 & 10 & 10 & 10 \\
\hline
\end{tabular}

Note: This table displays estimates of the fiscal outcome:

$\bar{y}_{i}=\alpha+v_{i}+\gamma \bar{s}_{i}+\delta \bar{x}_{i}+\phi \bar{w}_{i}+\eta \bar{z}_{i}+\varepsilon_{i t}$

Where an overbar denotes a time average of $y_{i t}$, the primary balance in country $i$ and year $t, s_{i t}$, the fiscal institutions index, $x_{i t}$, economic control variables, $\mathrm{w}_{i t}$, other control variables, and $z_{i}$, time-invariant institutional variables. The variable $v_{i}$ is a country specific component. Standard errors in parentheses, ${ }^{*}$ significant at $10 \%$; ** significant at $5 \%$; *** significant at $1 \%$ 
Table 6. Economic Factors, Budget Institutions, and Fiscal Performance: Evidence from Panel Data Regressions (Fixed Effects)

Primary balance-to-GDP ratio

\begin{tabular}{|c|c|c|c|c|c|c|c|}
\hline & (1) & (2) & (3) & (4) & (5) & (6) & (7) \\
\hline \multirow[t]{2}{*}{ Debt-to-GDP ratio } & 0.07 & & & & 0.05 & 0.03 & 0.02 \\
\hline & $(0.05)$ & & & & $(0.05)$ & $(0.04)$ & $(0.05)$ \\
\hline \multirow[t]{2}{*}{ Unemployment rate } & & -0.34 & & & -0.34 & -0.41 & -0.48 \\
\hline & & $(0.16)^{* *}$ & & & $(0.17)^{*}$ & $(0.15)^{* *}$ & $(0.17)^{* * *}$ \\
\hline \multirow[t]{2}{*}{ Inflation } & & & 0.05 & & 0.06 & 0.14 & 0.11 \\
\hline & & & $(0.07)$ & & $(0.06)$ & $(0.06)^{* *}$ & $(0.07)^{*}$ \\
\hline \multirow[t]{2}{*}{ Openness } & & & & 1.58 & 4.78 & 7.89 & 7.95 \\
\hline & & & & $(4.87)$ & $(4.91)$ & $(4.42)^{*}$ & $(4.42)^{*}$ \\
\hline $\begin{array}{l}\text { Fiscal institutions } \\
\text { index }\end{array}$ & & & & & & $\begin{array}{c}7.52 \\
(2.08) * * *\end{array}$ & $\begin{array}{c}7.97 \\
(2.12) * * *\end{array}$ \\
\hline EU accession dummy & & & & & & & $\begin{array}{l}-1.46 \\
(1.42)\end{array}$ \\
\hline Time dummies & $\mathrm{Y}$ & $\mathrm{Y}$ & $\mathrm{Y}$ & $\mathrm{Y}$ & $\mathrm{Y}$ & $\mathrm{Y}$ & $\mathrm{Y}$ \\
\hline Observations & 63 & 63 & 63 & 63 & 63 & 63 & 63 \\
\hline Number of countries & 10 & 10 & 10 & 10 & 10 & 10 & 10 \\
\hline
\end{tabular}

Note: This table displays estimates of the fiscal outcome:

$y_{i t}=\alpha+v_{i}+\gamma s_{i t}+\delta x_{i t}+\phi w_{i t}+\varepsilon_{i t}$

where $y_{i t}$ is the primary balance in country $i$ and year $t ; v_{i}$ is a country specific component; $s_{i t}$ is the fiscal institutions index; $x_{i t}$ comprises economic control variables; $\mathrm{w}_{i t}$ are other control variables. Estimations of panel data regressions using random effects are reported. Standard errors in parentheses, * significant at 10\%; ** significant at 5\%; *** significant at $1 \%$. 
Table 7. Government Fragmentation, Ideology, and Fiscal Performance: Evidence from Panel Data Regressions (Fixed Effects)

Primary balance-to-GDP ratio

\begin{tabular}{lcccccc}
\hline & $(1)$ & $(2)$ & $(3)$ & $(4)$ & $(5)$ & $(6)$ \\
\hline Government & -0.82 & & & & & 6.23 \\
fragmentation & $(1.81)$ & & & & & $(2.74)^{* *}$ \\
& & & & & & \\
Government ideology: & & & & & & \\
$\quad$ Right/left & & 0.07 & & & 0.16 & 0.49 \\
& & $(0.13)$ & & & $(0.12)$ & $(0.19)^{* *}$ \\
$\quad$ Nationalism & & & -0.24 & & -0.39 & -0.66 \\
& & & $(0.13)^{*}$ & & $(0.15)^{* * *}$ & $(0.18)^{* * *}$ \\
$\quad$ Centralization & & & & 0.06 & 0.30 & 0.48 \\
& & & & $(0.18)$ & $(0.20)$ & $(0.20)^{* *}$ \\
& $\mathrm{Y}$ & $\mathrm{Y}$ & $\mathrm{Y}$ & $\mathrm{Y}$ & $\mathrm{Y}$ & $\mathrm{Y}$ \\
& 63 & 63 & 63 & 63 & 63 & 63 \\
Time dummies & 10 & 10 & 10 & 10 & 10 & 10 \\
Observations & & & & & & \\
Number of countries & & & & & & \\
\hline \hline
\end{tabular}

Note: This table displays estimates of the fiscal outcome:

$y_{i t}=\alpha+v_{i}+\gamma S_{i t}+\phi w_{i t}+\varepsilon_{i t}$

where $y_{i t}$ is the primary balance in country $i$ and year $t ; v_{i}$ is a country specific component; $s_{i t}$ is the fiscal institutions index; $\mathrm{w}_{i t}$ are political control variables. Estimations of panel data regressions using random effects are reported. Standard errors in parentheses, $*$ significant at $10 \% ; * *$ significant at $5 \% ; * * *$ significant at $1 \%$. 
Table 8. Explaining Fiscal Performance: Economics Versus Politics, Evidence from Alternative Panel Data Estimation Procedures

\begin{tabular}{|c|c|c|c|c|c|c|}
\hline & \multicolumn{6}{|c|}{ Primary balance-to-GDP ratio } \\
\hline & $(1)$ & $(2)$ & (3) & (4) & $(5)$ & $(6)$ \\
\hline & $\begin{array}{l}\text { Random } \\
\text { Effects }\end{array}$ & $\begin{array}{c}\text { Fixed } \\
\text { Effects }\end{array}$ & $\begin{array}{c}\text { Fixed } \\
\text { Effects }\end{array}$ & $\begin{array}{l}\text { Arellano- } \\
\text { Bond }\end{array}$ & $\begin{array}{l}\text { Kiviet-bias } \\
\text { Adjustment }\end{array}$ & $\begin{array}{c}\text { Fixed } \\
\text { Effects }\end{array}$ \\
\hline $\begin{array}{l}\text { Debt-to-GDP ratio } \\
\text { (lagged) }\end{array}$ & $\begin{array}{c}0.09 \\
(0.02)^{* * *}\end{array}$ & $\begin{array}{c}0.02 \\
(0.05)\end{array}$ & $\begin{array}{c}0.02 \\
(0.05)\end{array}$ & $\begin{array}{c}0.07 \\
(0.07)\end{array}$ & $\begin{array}{c}0.01 \\
(0.08)\end{array}$ & \\
\hline Unemployment rate & $\begin{array}{l}-0.08 \\
(0.08)\end{array}$ & $\begin{array}{l}-0.23 \\
(0.18)\end{array}$ & $\begin{array}{c}-0.31 \\
(0.17)^{*}\end{array}$ & $\begin{array}{l}-0.09 \\
(0.26)\end{array}$ & $\begin{array}{l}-0.03 \\
(0.19)\end{array}$ & $\begin{array}{c}-0.33 \\
(0.16)^{*}\end{array}$ \\
\hline Inflation & $\begin{array}{c}0.16 \\
(0.04)^{* * *}\end{array}$ & $\begin{array}{c}0.07 \\
(0.08)\end{array}$ & $\begin{array}{c}0.12 \\
(0.08)\end{array}$ & $\begin{array}{c}0.18 \\
(0.12)\end{array}$ & $\begin{array}{c}0.13 \\
(0.13)\end{array}$ & $\begin{array}{c}0.12 \\
(0.08)\end{array}$ \\
\hline Openness index & $\begin{array}{c}3.62 \\
(1.57)^{* *}\end{array}$ & $\begin{array}{c}7.39 \\
(4.77)\end{array}$ & $\begin{array}{c}8.80 \\
(4.40) *\end{array}$ & $\begin{array}{c}12.66 \\
(5.25)^{* *}\end{array}$ & $\begin{array}{c}13.78 \\
(5.28)^{* *}\end{array}$ & $\begin{array}{c}8.96 \\
(4.35)^{* *}\end{array}$ \\
\hline Government fragmentation & $\begin{array}{c}1.78 \\
(1.72)\end{array}$ & $\begin{array}{c}6.78 \\
(2.96)^{* *}\end{array}$ & $\begin{array}{c}4.39 \\
(2.84)\end{array}$ & $\begin{array}{c}6.13 \\
(3.39)^{*}\end{array}$ & $\begin{array}{c}6.86 \\
(3.12)^{* *}\end{array}$ & $\begin{array}{c}4.66 \\
(2.76)^{*}\end{array}$ \\
\hline Government ideology: & & & & & & \\
\hline Left/right & $\begin{array}{c}0.38 \\
(0.12)^{* * *}\end{array}$ & $\begin{array}{c}0.49 \\
(0.19)^{* *}\end{array}$ & $\begin{array}{c}0.37 \\
(0.18)^{* *}\end{array}$ & $\begin{array}{c}0.29 \\
(0.21)\end{array}$ & $\begin{array}{c}0.40 \\
(0.21)^{*}\end{array}$ & $\begin{array}{c}0.39 \\
(0.17)^{* *}\end{array}$ \\
\hline Nationalism & $\begin{array}{c}-0.25 \\
(0.16)\end{array}$ & $\begin{array}{c}-0.63 \\
(0.20)^{* * *}\end{array}$ & $\begin{array}{c}-0.46 \\
(0.19)^{* *}\end{array}$ & $\begin{array}{c}-0.60 \\
(0.24)^{* *}\end{array}$ & $\begin{array}{c}-0.68 \\
(0.24)^{* * *}\end{array}$ & $\begin{array}{c}-0.48 \\
(0.19)^{* *}\end{array}$ \\
\hline Decentralization & $\begin{array}{r}0.34 \\
(0.2)\end{array}$ & $\begin{array}{c}0.46 \\
(0.26)^{*}\end{array}$ & $\begin{array}{c}0.38 \\
(0.24)\end{array}$ & $\begin{array}{c}0.63 \\
(0.32)^{*}\end{array}$ & $\begin{array}{c}0.57 \\
(0.27)^{* *}\end{array}$ & $\begin{array}{c}0.36 \\
(0.24)\end{array}$ \\
\hline Fiscal institutions index & $\begin{array}{c}5.09 \\
(1.19)^{* * *}\end{array}$ & & $\begin{array}{c}6.20 \\
(2.13)^{* * *}\end{array}$ & $\begin{array}{c}9.03 \\
(4.42)^{* *}\end{array}$ & $\begin{array}{c}7.37 \\
(4.47)^{*}\end{array}$ & $\begin{array}{c}6.15 \\
(2.10)^{* * *}\end{array}$ \\
\hline Lagged primary balance & & & & $\begin{array}{c}0.11 \\
(0.21)\end{array}$ & $\begin{array}{c}0.01 \\
(0.08)\end{array}$ & \\
\hline Time dummies & Y & $\mathrm{Y}$ & $\mathrm{Y}$ & Y & $\mathrm{Y}$ & Y \\
\hline Observations & 63 & 63 & 63 & 43 & 53 & 63 \\
\hline Number of countries & 10 & 10 & 10 & 10 & 10 & 10 \\
\hline
\end{tabular}

Note: This table displays estimates of the fiscal outcome:

$y_{i t}=\alpha+v_{i}+\beta_{t} u_{t}+\gamma s_{i t}+\delta x_{i t}+\phi w_{i t}+\varepsilon_{i t}$

where $y_{i t}$ is the primary balance in country $i$ and year $t$; $u_{t}$ represents variables common to all countries; $v_{i}$ is a country specific component; $s_{i t}$ is the fiscal institutions index; $x_{i t}$ comprises economic control variables; and $\mathrm{w}_{i t}$ are political control variables. Column 1 reports results of a panel data regression using random effects. Columns 2, 3, and 6 are the results of panel data regression using fixed effects. In column 4, estimates of the coefficients using Arellano-bond method are shown (in this case, the Sargan test reject the hypothesis of over-identification, $\left(\operatorname{Pr} \geq \chi^{2}=0.27\right)$, and the hypothesis that average autocorrelation in residuals of order two is zero cannot be rejected ( $\mathrm{Pr} \geq \mathrm{z}=0.93$ ). Column 5 reports bias-corrected LSDV estimates for dynamics unbalanced panel data models (Bruno 2005). Standard errors in parentheses, * significant at 10\%; ** significant at 5\%; *** significant at $1 \%$. 
Table 9. Explaining Fiscal Performance: Economics Versus Politics, Evidence from Panel Data Regressions (Fixed Effects)

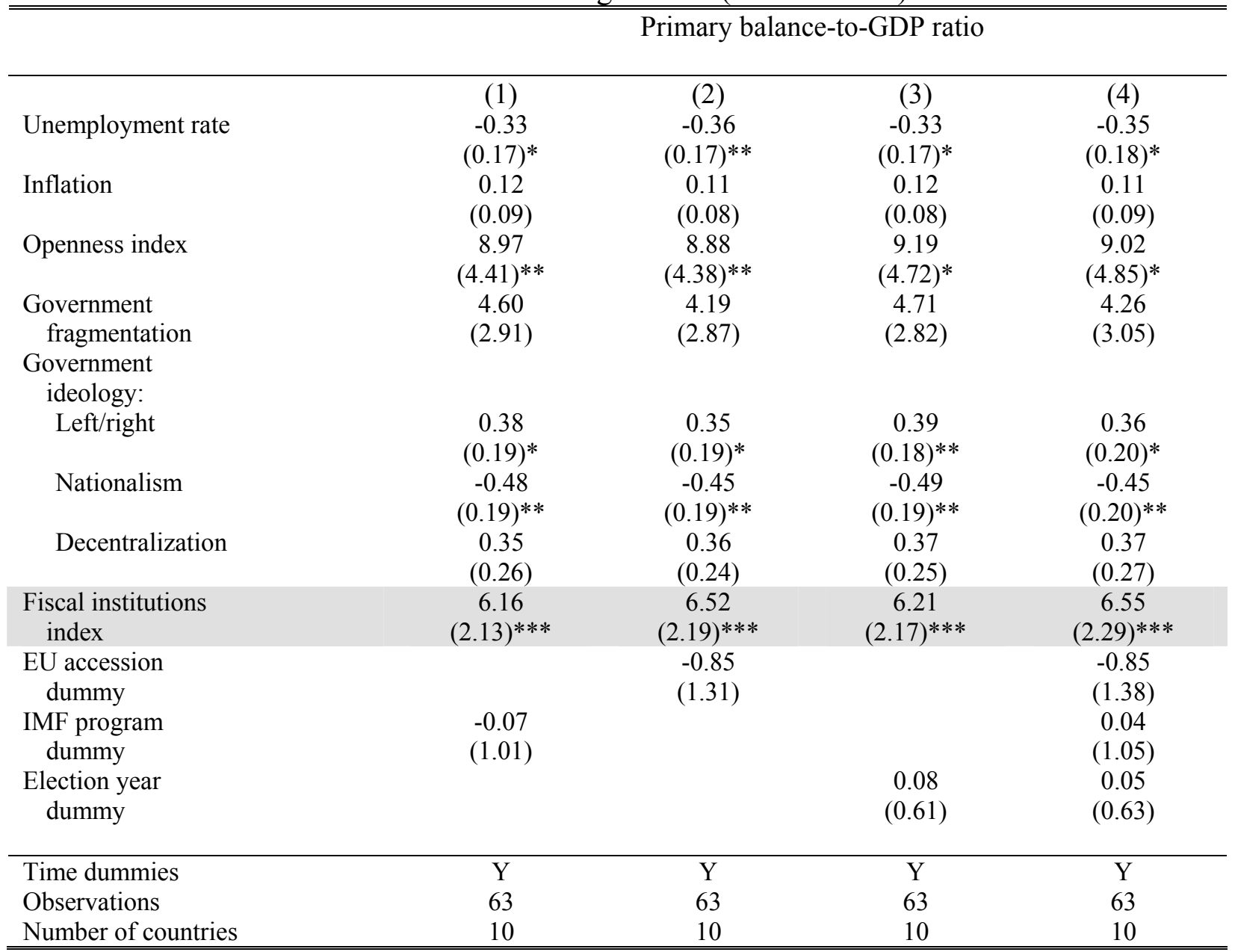

Note: This table displays estimates of the same fiscal outcome as in Table 8. Standard errors in parentheses, * significant at $10 \%$;* significant at 5\%; *** significant at $1 \%$ 
Table 10. How Important Are the Deeper Determinants?

Evidence from Nonlinear Least Squares Regressions

\begin{tabular}{|c|c|c|c|c|c|c|}
\hline \multirow[b]{2}{*}{ Constant } & \multicolumn{6}{|c|}{ Primary balance-to-GDP ratio } \\
\hline & $\begin{array}{c}-0.05 \\
(12.28)\end{array}$ & $\begin{array}{l}-7.49 \\
(6.24)\end{array}$ & $\begin{array}{l}-11.82 \\
(6.13)\end{array}$ & $\begin{array}{c}4.07 \\
(13.85)\end{array}$ & $\begin{array}{l}-7.07 \\
(6.43)\end{array}$ & $\begin{array}{l}-12.13 \\
(6.26)\end{array}$ \\
\hline Inflation & $\begin{array}{c}0.06 \\
(0.05)\end{array}$ & $\begin{array}{c}0.06 \\
(0.04)\end{array}$ & $\begin{array}{c}0.06 \\
(0.05)\end{array}$ & $\begin{array}{c}0.11 \\
(0.07)\end{array}$ & $\begin{array}{c}0.10 \\
(0.07)\end{array}$ & $\begin{array}{c}0.09 \\
(0.07)\end{array}$ \\
\hline Unemployment rate & $\begin{array}{c}0.19 \\
(0.13)\end{array}$ & $\begin{array}{c}0.21 \\
(0.13)\end{array}$ & $\begin{array}{c}0.14 \\
(0.14)\end{array}$ & $\begin{array}{c}0.32 \\
(0.18)^{*}\end{array}$ & $\begin{array}{c}0.33 \\
(0.18)^{*}\end{array}$ & $\begin{array}{c}0.16 \\
(0.18)\end{array}$ \\
\hline Openness index & $\begin{array}{c}1.65 \\
(2.30)\end{array}$ & & & $\begin{array}{c}3.29 \\
(3.60)\end{array}$ & & \\
\hline Fiscal institutions index & $\begin{array}{c}5.47 \\
(2.45)^{* *}\end{array}$ & $\begin{array}{c}5.38 \\
(2.40)^{* *}\end{array}$ & $\begin{array}{c}5.86 \\
(2.33)^{* *}\end{array}$ & $\begin{array}{c}6.28 \\
(2.52)^{* *}\end{array}$ & $\begin{array}{c}6.08 \\
(2.47)^{* *}\end{array}$ & $\begin{array}{c}6.17 \\
(2.38)^{* *}\end{array}$ \\
\hline Government fragmentation & $\begin{array}{c}8.12 \\
(2.87)^{* * *}\end{array}$ & $\begin{array}{c}7.69 \\
(2.83)^{* *}\end{array}$ & $\begin{array}{c}6.10 \\
(2.72)^{* *}\end{array}$ & $\begin{array}{c}9.74 \\
(2.99)^{* * *}\end{array}$ & $\begin{array}{c}9.06 \\
(2.96)^{* * *}\end{array}$ & $\begin{array}{c}6.37 \\
(2.79)^{*}\end{array}$ \\
\hline Government ideology: & & & & & & \\
\hline Left/right & $\begin{array}{c}0.46 \\
(0.18)^{* * *}\end{array}$ & $\begin{array}{c}0.45 \\
(0.18)^{* *}\end{array}$ & $\begin{array}{c}0.42 \\
(0.18)^{* *}\end{array}$ & $\begin{array}{c}0.55 \\
(0.18)^{* * *}\end{array}$ & $\begin{array}{c}0.52 \\
(0.18)^{* * *}\end{array}$ & $\begin{array}{c}0.43 \\
(0.18)^{* * *}\end{array}$ \\
\hline Nationalism & $\begin{array}{c}-0.77 \\
(0.21)^{* * *}\end{array}$ & $\begin{array}{c}-0.75 \\
(0.21)^{* * *}\end{array}$ & $\begin{array}{c}-0.74 \\
(0.21)^{* * *}\end{array}$ & $\begin{array}{c}-0.88 \\
(0.22)^{* * *}\end{array}$ & $\begin{array}{c}-0.85 \\
(0.22)^{* * *}\end{array}$ & $\begin{array}{c}-0.78 \\
(0.23)^{* * *}\end{array}$ \\
\hline Fiscal decentralization & $\begin{array}{c}0.95 \\
(0.30)^{* * *}\end{array}$ & $\begin{array}{c}1.01 \\
(0.29)^{* * *}\end{array}$ & $\begin{array}{c}0.98 \\
(0.31)^{* * *}\end{array}$ & $\begin{array}{c}1.05 \\
(0.30)^{* * *}\end{array}$ & $\begin{array}{c}1.10 \\
(0.30)^{* * *}\end{array}$ & $\begin{array}{c}1.02 \\
(0.33)^{* * *}\end{array}$ \\
\hline Time-invariant variables: & & & & & & \\
\hline Ethnic fractionalization & $\begin{array}{l}-4.34 \\
(3.02)\end{array}$ & $\begin{array}{l}-3.59 \\
(2.73)\end{array}$ & & $\begin{array}{c}-3.75 \\
(1.73)^{* *}\end{array}$ & $\begin{array}{c}-3.08 \\
(1.65)^{*}\end{array}$ & \\
\hline District magnitude & $\begin{array}{c}-1.44 \\
(0.85)^{*}\end{array}$ & $\begin{array}{c}-1.34 \\
(0.70)^{*}\end{array}$ & $\begin{array}{c}-1.18 \\
(0.64)^{*}\end{array}$ & $\begin{array}{c}-0.96 \\
(0.46)^{* *}\end{array}$ & $\begin{array}{c}-0.90 \\
(0.41)^{* *}\end{array}$ & $\begin{array}{l}-0.92 \\
(0.55)\end{array}$ \\
\hline Voter turnover & $\begin{array}{c}-0.13 \\
(0.05)^{* *}\end{array}$ & $\begin{array}{c}-0.12 \\
(0.05)^{* *}\end{array}$ & $\begin{array}{c}-0.09 \\
(0.04)^{* *}\end{array}$ & $\begin{array}{c}-0.09 \\
(0.03)^{* * *}\end{array}$ & $\begin{array}{c}-0.08 \\
(0.03)^{* * *}\end{array}$ & $\begin{array}{c}-0.07 \\
(0.04)^{*}\end{array}$ \\
\hline Debt-to-GDP ratio & & & & $\begin{array}{c}-0.12 \\
(0.01)^{* *}\end{array}$ & $\begin{array}{c}-0.11 \\
(0.01)^{* *}\end{array}$ & $\begin{array}{c}-0.01 \\
(0.01) \\
\end{array}$ \\
\hline Time dummies & $\mathrm{Y}$ & $\mathrm{Y}$ & $\mathrm{Y}$ & $\mathrm{Y}$ & $\mathrm{Y}$ & $\mathrm{Y}$ \\
\hline Country dummies & $\mathrm{Y}$ & $\mathrm{Y}$ & $\mathrm{Y}$ & $\mathrm{Y}$ & $\mathrm{Y}$ & $\mathrm{Y}$ \\
\hline Observations & 63 & 63 & 63 & 63 & 63 & 63 \\
\hline Adjusted R-squared & 0.63 & 0.63 & 0.63 & 0.64 & 0.64 & 0.64 \\
\hline
\end{tabular}

Note: This table displays non-linear least squares estimates of the fiscal outcome:

$y_{i t}=\alpha+\left[1+\lambda\left(z_{i}-\bar{z}\right)\right]\left(\beta u_{t}+\delta x_{i t}\right)+\gamma s_{i t}+\phi w_{i t}+\left(v_{i}+\eta z_{i}\right)+\varepsilon_{i t}$

where $y_{i t}$ is the primary-balance-to-GDP ratio in country $i$ and year $t ; u_{t}$ represents variables common to all countries; $v_{i}$ is a country specific component; $s_{i t}$ is the fiscal institutions index; $\mathrm{w}_{i t}$ are country-specific control variables; and $z_{i}$ are timeinvariant institutional variables. Idiosyncratic economic variables $x_{i t}$ include inflation, unemployment rate, and openness index. Time-invariant terms interact with time dummies and idiosyncratic economic variables $x_{i t}$ In columns 4-6 debt-to-GDP ratio is treated as a time-invariant variables. Standard errors in parentheses, ${ }^{*}$ significant at $10 \%$; $* *$ significant at $5 \%$; $* * *$ significant at $1 \%$. 
Table 11. How Important Are the Deeper Determinants?

Evidence from Nonlinear Least Squares Regressions

\begin{tabular}{|c|c|c|c|c|c|c|}
\hline \multirow[b]{2}{*}{ Constant } & \multicolumn{6}{|c|}{ Primary balance-to-GDP ratio } \\
\hline & $\begin{array}{c}18.50 \\
(14.75)\end{array}$ & $\begin{array}{c}8.93 \\
(8.14)\end{array}$ & $\begin{array}{c}6.51 \\
(8.34)\end{array}$ & $\begin{array}{c}28.59 \\
(17.48)\end{array}$ & $\begin{array}{l}12.35 \\
(8.84)\end{array}$ & $\begin{array}{c}6.71 \\
(8.56)\end{array}$ \\
\hline Inflation & $\begin{array}{c}0.06 \\
(0.04)\end{array}$ & $\begin{array}{c}0.06 \\
(0.04)\end{array}$ & $\begin{array}{c}0.07 \\
(0.05)\end{array}$ & $\begin{array}{c}0.12 \\
(0.07)\end{array}$ & $\begin{array}{c}0.10 \\
(0.07)\end{array}$ & $\begin{array}{c}0.07 \\
(0.06)\end{array}$ \\
\hline Unemployment rate & $\begin{array}{c}0.19 \\
(0.12)\end{array}$ & $\begin{array}{c}0.21 \\
(0.12)^{*}\end{array}$ & $\begin{array}{c}0.15 \\
(0.13)\end{array}$ & $\begin{array}{c}0.31 \\
(0.15)^{* *}\end{array}$ & $\begin{array}{c}0.32 \\
(0.16)^{*}\end{array}$ & $\begin{array}{c}0.16 \\
(0.15)\end{array}$ \\
\hline Openness index & $\begin{array}{c}2.10 \\
(2.19)\end{array}$ & & & $\begin{array}{c}4.24 \\
(3.38)\end{array}$ & & \\
\hline Fiscal institutions index & $\begin{array}{c}2.35 \\
(0.86)^{* *}\end{array}$ & $\begin{array}{c}2.40 \\
(0.87)^{* * *}\end{array}$ & $\begin{array}{c}3.08 \\
(1.08)^{* * *}\end{array}$ & $\begin{array}{c}3.99 \\
(1.52)^{* *}\end{array}$ & $\begin{array}{c}3.75 \\
(1.46)^{* *}\end{array}$ & $\begin{array}{c}3.29 \\
(1.57)^{* *}\end{array}$ \\
\hline Government fragmentation & $\begin{array}{c}8.34 \\
(2.72)^{* * *}\end{array}$ & $\begin{array}{c}7.82 \\
(2.67)^{* * *}\end{array}$ & $\begin{array}{c}6.09 \\
(2.65)^{* *}\end{array}$ & $\begin{array}{c}10.07 \\
(2.81)^{* * *}\end{array}$ & $\begin{array}{c}9.23 \\
(2.80)^{* * *}\end{array}$ & $\begin{array}{c}6.16 \\
(2.72)^{* *}\end{array}$ \\
\hline Government ideology: & & & & & & \\
\hline Left/right & $\begin{array}{c}0.49 \\
(0.17)^{* * *}\end{array}$ & $\begin{array}{c}0.47 \\
(0.17)^{* * *}\end{array}$ & $\begin{array}{c}0.41 \\
(0.17)^{* *}\end{array}$ & $\begin{array}{c}0.59 \\
(0.17)^{* * *}\end{array}$ & $\begin{array}{c}0.55 \\
(0.17)^{* * *}\end{array}$ & $\begin{array}{c}0.42 \\
(0.18)^{* *}\end{array}$ \\
\hline Nationalism & $\begin{array}{c}-0.78 \\
(0.20) * * *\end{array}$ & $\begin{array}{c}-0.74 \\
(0.17)^{* * *}\end{array}$ & $\begin{array}{c}-0.75 \\
(0.21)^{* * *}\end{array}$ & $\begin{array}{c}-0.88 \\
(0.20)^{* * *}\end{array}$ & $\begin{array}{c}-0.84 \\
(0.21)^{* * *}\end{array}$ & $\begin{array}{c}-0.76 \\
(0.23)^{* * *}\end{array}$ \\
\hline Fiscal decentralization & $\begin{array}{c}0.96 \\
(0.28)^{* * *}\end{array}$ & $\begin{array}{c}1.03 \\
(0.28)^{* * *}\end{array}$ & $\begin{array}{c}1.01 \\
(0.30)^{* * *}\end{array}$ & $\begin{array}{c}1.04 \\
(0.27)^{* * *}\end{array}$ & $\begin{array}{c}1.12 \\
(0.29)^{* * *}\end{array}$ & $\begin{array}{c}1.03 \\
(0.32)^{* * *}\end{array}$ \\
\hline Time-invariant variables: & & & & & & \\
\hline Ethnic fractionalization & $\begin{array}{l}-4.78 \\
(2.92)\end{array}$ & $\begin{array}{l}-3.95 \\
(2.63)\end{array}$ & & $\begin{array}{c}-4.47 \\
(1.72)^{* *}\end{array}$ & $\begin{array}{c}-3.67 \\
(1.68)^{* *}\end{array}$ & \\
\hline District magnitude & $\begin{array}{c}-1.32 \\
(0.71)^{*}\end{array}$ & $\begin{array}{c}-1.24 \\
(0.59)^{* *}\end{array}$ & $\begin{array}{c}-1.05 \\
(0.51)^{* *}\end{array}$ & $\begin{array}{c}-0.91 \\
(0.40)^{* *}\end{array}$ & $\begin{array}{c}-0.87 \\
(0.36)^{* *}\end{array}$ & $\begin{array}{c}-0.99 \\
(0.58)^{* *}\end{array}$ \\
\hline Voter turnover & $\begin{array}{c}-0.15 \\
(0.06)^{* *}\end{array}$ & $\begin{array}{c}-0.13 \\
(0.05)^{* * *}\end{array}$ & $\begin{array}{c}-0.10 \\
(0.04)^{* *}\end{array}$ & $\begin{array}{c}-0.11 \\
(0.03)^{* * *}\end{array}$ & $\begin{array}{c}-0.10 \\
(0.03)^{* * *}\end{array}$ & $\begin{array}{c}-0.09 \\
(0.05)^{* *}\end{array}$ \\
\hline Debt-to-GDP ratio & & & & $\begin{array}{c}-0.01 \\
(0.01)^{* *}\end{array}$ & $\begin{array}{c}-0.01 \\
(0.01)^{* *}\end{array}$ & $\begin{array}{c}-0.00 \\
(0.01)\end{array}$ \\
\hline Time dummies & $\mathrm{Y}$ & $\mathrm{Y}$ & $\mathrm{Y}$ & $\mathrm{Y}$ & $\mathrm{Y}$ & $\mathrm{Y}$ \\
\hline Country dummies & $\mathrm{Y}$ & $\mathrm{Y}$ & $\mathrm{Y}$ & $\mathrm{Y}$ & $\mathrm{Y}$ & $\mathrm{Y}$ \\
\hline Observations & 63 & 63 & 63 & 63 & 63 & 63 \\
\hline Adjusted R-squared & 0.66 & 0.63 & 0.64 & 0.67 & 0.67 & 0.63 \\
\hline
\end{tabular}

Note: This table displays non-linear least squares estimates of the same fiscal outcome as in Table 10.

The variables $x_{i t}$ include inflation, unemployment rate, openness index, and fiscal institutions index. Time-invariant terms interact with time dummies and idiosyncratic economic variables $x_{i t}$ In columns 4-6 debt-to-GDP ratio is treated as a timeinvariant variables. Standard errors in parentheses, * significant at 10\%;** significant at 5\%; *** significant at $1 \%$. 
Table 12. Budget Process Stages and the Delegation/Contract-Based Approaches: Evidence from Nonlinear Least Squares Regressions

Primary balance-to-GDP ratio

\begin{tabular}{|c|c|c|c|c|c|c|}
\hline & 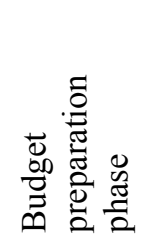 & 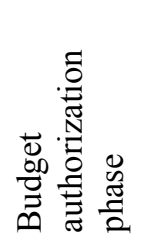 & 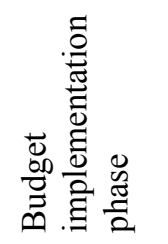 & 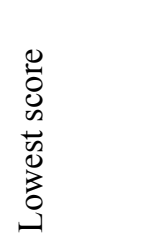 & 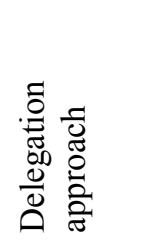 & 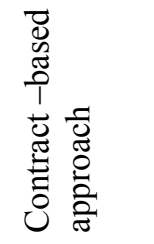 \\
\hline const & $\begin{array}{l}2.96 \\
(7.28)\end{array}$ & $\begin{array}{l}0.29 \\
(6.19)\end{array}$ & $\begin{array}{l}19.63 \\
(18.42)\end{array}$ & $\begin{array}{l}1.15 \\
(6.38)\end{array}$ & $\begin{array}{l}14.99 \\
(11.28)\end{array}$ & $\begin{array}{l}6.02 \\
(7.98)\end{array}$ \\
\hline Inflation & $\begin{array}{l}0.04 \\
(0.05)\end{array}$ & $\begin{array}{l}0.07 \\
(0.05)\end{array}$ & $\begin{array}{l}0.02 \\
(0.03)\end{array}$ & $\begin{array}{l}0.07 \\
(0.05)\end{array}$ & $\begin{array}{l}0.08 \\
(0.05)\end{array}$ & $\begin{array}{l}0.07 \\
(0.05)\end{array}$ \\
\hline Unemployment rate & $\begin{array}{l}0.13 \\
(0.14)\end{array}$ & $\begin{array}{l}0.18 \\
(0.14)\end{array}$ & $\begin{array}{l}0.02 \\
(0.12)\end{array}$ & $\begin{array}{l}0.19 \\
(0.14)\end{array}$ & $\begin{array}{l}0.15 \\
(0.13)\end{array}$ & $\begin{array}{l}0.14 \\
(0.13)\end{array}$ \\
\hline Fiscal institutions index & $\begin{array}{l}2.9 \\
(1.41)^{* *}\end{array}$ & $\begin{array}{l}1.33 \\
(0.53) * *\end{array}$ & $\begin{array}{l}3.79 \\
(1.36) * * *\end{array}$ & $\begin{array}{l}1.92 \\
(0.85)^{* *}\end{array}$ & $\begin{array}{l}4.49 \\
(1.47)^{* * *}\end{array}$ & $\begin{array}{l}2.95 \\
(0.95)^{* * *}\end{array}$ \\
\hline Government fragmentation & $\begin{array}{l}6.18 \\
(2.80)^{* *}\end{array}$ & $\begin{array}{l}6.31 \\
(2.72)^{* *}\end{array}$ & $\begin{array}{l}7.47 \\
(2.60)^{* * *}\end{array}$ & $\begin{array}{l}6.30 \\
(2.76)^{* *}\end{array}$ & $\begin{array}{l}6.34 \\
(2.58)^{* *}\end{array}$ & $\begin{array}{l}6.26 \\
(2.58)^{* *}\end{array}$ \\
\hline \multicolumn{7}{|l|}{ Government ideology: } \\
\hline Left/right & $\begin{array}{l}0.47 \\
(0.18)^{* *}\end{array}$ & $\begin{array}{l}0.40 \\
(0.18)^{* *}\end{array}$ & $\begin{array}{l}0.49 \\
(0.18)^{* * *}\end{array}$ & $\begin{array}{l}0.43 \\
(0.18)^{* *}\end{array}$ & $\begin{array}{l}0.41 \\
(0.17)^{* *}\end{array}$ & $\begin{array}{l}0.39 \\
(0.17)^{* *}\end{array}$ \\
\hline Nationalism & $\begin{array}{l}-0.75 \\
(0.21)^{* * *}\end{array}$ & $\begin{array}{l}-0.77 \\
(0.21)^{* * *}\end{array}$ & $\begin{array}{l}-0.68 \\
(0.20)^{* * *}\end{array}$ & $\begin{array}{l}-0.77 \\
(0.21)^{* * *}\end{array}$ & $\begin{array}{l}-0.73 \\
(0.20)^{* * *}\end{array}$ & $\begin{array}{l}-0.72 \\
(0.20)^{* * *}\end{array}$ \\
\hline Fiscal decentralization & $\begin{array}{l}1.04 \\
(0.32)^{* * *}\end{array}$ & $\begin{array}{l}1.04 \\
(0.31)^{* * *}\end{array}$ & $\begin{array}{l}0.72 \\
(0.29)^{* *}\end{array}$ & $\begin{array}{l}1.06 \\
(0.31)^{* * *}\end{array}$ & $\begin{array}{l}0.98 \\
(0.30)^{* * *}\end{array}$ & $\begin{array}{l}0.97 \\
(0.30)^{* * *}\end{array}$ \\
\hline \multicolumn{7}{|l|}{ Time-invariant variables: } \\
\hline District magnitude & $\begin{array}{l}-1.26 \\
(0.79)\end{array}$ & $\begin{array}{l}-0.92 \\
(0.45)^{* *}\end{array}$ & $\begin{array}{l}-1.80 \\
(0.69)^{* *}\end{array}$ & $\begin{array}{l}-1.00 \\
(0.55)^{*}\end{array}$ & $\begin{array}{l}-1.17 \\
(0.52)^{* *}\end{array}$ & $\begin{array}{l}-1.13 \\
(0.47)^{* *}\end{array}$ \\
\hline Voter turnover & $\begin{array}{l}-0.12 \\
(0.05)^{* *}\end{array}$ & $\begin{array}{l}-0.10 \\
(0.04)^{* *}\end{array}$ & $\begin{array}{l}-0.04 \\
(0.06) \\
\end{array}$ & $\begin{array}{l}-0.11 \\
(0.4)^{* * *}\end{array}$ & $\begin{array}{l}-0.11 \\
(0.04)^{* *}\end{array}$ & $\begin{array}{l}-0.09 \\
(0.04)^{* *}\end{array}$ \\
\hline Time dummies & $\mathrm{Y}$ & $\mathrm{Y}$ & $\mathrm{Y}$ & $\mathrm{Y}$ & $\mathrm{Y}$ & $\mathrm{Y}$ \\
\hline Country dummies & $\mathrm{Y}$ & $\mathrm{Y}$ & $\mathrm{Y}$ & $\mathrm{Y}$ & $\mathrm{Y}$ & $\mathrm{Y}$ \\
\hline Observations & 63 & 63 & 63 & 63 & 63 & 63 \\
\hline Adjusted R-squared & 0.61 & 0.62 & 0.64 & 0.61 & 0.65 & 0.65 \\
\hline
\end{tabular}

Note: This table displays non-linear least squares estimates of the same fiscal outcome as in Table 10.

Time-invariant variables interact with time dummies and the idiosyncratic variables $x_{i t}$ unemployment rate, openness, and fiscal institutions index. The fiscal institutions index in the first column is the budget preparation index, in the second column the budget authorization index, and in the third column the budget implementation index. In the fourth column, the fiscal institutions index is built by taking the lowest score among the three indexes used in the first three columns for each year. In the fifth column, the fiscal institutions index is constructed by taking into account the features relevant for the delegation approach; in the last column the characteristics relevant in a contract-based setting are considered. Standard errors in parentheses, * significant at $10 \% ; * *$ significant at $5 \% ; * * *$ significant at $1 \%$. 
Table 13. Expenditure and Revenue Developments: The Role of Economics and Politics, Evidence from Panel Data Regressions (Seemingly Unrelated Regressions Estimates)

\begin{tabular}{|c|c|c|c|c|c|c|}
\hline & \multicolumn{2}{|c|}{ EU15 growth shock } & \multicolumn{2}{|c|}{ Oil price shock } & \multicolumn{2}{|c|}{$\begin{array}{c}\text { France/Germany primary } \\
\text { balance }\end{array}$} \\
\hline & $\begin{array}{l}\text { Exp-to- } \\
\text { GDP }\end{array}$ & $\begin{array}{l}\text { Rev-to- } \\
\text { GDP }\end{array}$ & $\begin{array}{l}\text { Exp-to- } \\
\text { GDP }\end{array}$ & $\begin{array}{l}\text { Rev-to- } \\
\text { GDP }\end{array}$ & $\begin{array}{l}\text { Exp-to- } \\
\text { GDP }\end{array}$ & $\begin{array}{l}\text { Rev-to- } \\
\text { GDP }\end{array}$ \\
\hline Lagged expenditure & $\begin{array}{l}0.38 \\
(0.08)^{* * *}\end{array}$ & & $\begin{array}{l}0.38 \\
(0.08) * * *\end{array}$ & & $\begin{array}{l}0.38 \\
(0.08) * * *\end{array}$ & \\
\hline Lagged revenue & & $\begin{array}{l}0.26 \\
(0.08) * * *\end{array}$ & & $\begin{array}{l}0.26 \\
(0.08) * * *\end{array}$ & & $\begin{array}{l}0.26 \\
(0.08) * * *\end{array}$ \\
\hline Unemployment rate & $\begin{array}{l}0.41 \\
(0.13)^{* * *}\end{array}$ & $\begin{array}{l}0.08 \\
(0.08)\end{array}$ & $\begin{array}{l}0.41 \\
(0.13) * * *\end{array}$ & $\begin{array}{l}0.08 \\
(0.08)\end{array}$ & $\begin{array}{l}0.41 \\
(0.13)^{* * *}\end{array}$ & $\begin{array}{l}0.08 \\
(0.08)\end{array}$ \\
\hline Inflation & $\begin{array}{l}-0.02 \\
(0.06)\end{array}$ & $\begin{array}{l}0.06 \\
(0.04)\end{array}$ & $\begin{array}{l}-0.02 \\
(0.06)\end{array}$ & $\begin{array}{l}0.06 \\
(0.04)\end{array}$ & $\begin{array}{l}-0.02 \\
(0.06)\end{array}$ & $\begin{array}{l}0.06 \\
(0.04)\end{array}$ \\
\hline Openness & $\begin{array}{l}-6.46 \\
(3.33)^{*}\end{array}$ & $\begin{array}{l}0.77 \\
(2.25)\end{array}$ & $\begin{array}{l}-6.46 \\
(3.33)^{*}\end{array}$ & $\begin{array}{l}0.77 \\
(2.25)\end{array}$ & $\begin{array}{l}-6.46 \\
(3.33)\end{array}$ & $\begin{array}{l}0.77 \\
(2.25)\end{array}$ \\
\hline $\begin{array}{l}\text { Government } \\
\text { fragmentation } \\
\text { Government ideology. }\end{array}$ & $\begin{array}{l}1.80 \\
(2.08)\end{array}$ & $\begin{array}{l}2.12 \\
(1.42)\end{array}$ & $\begin{array}{l}1.80 \\
(2.08)\end{array}$ & $\begin{array}{l}2.12 \\
(1.42)\end{array}$ & $\begin{array}{l}1.80 \\
(2.08)\end{array}$ & $\begin{array}{l}2.12 \\
(1.42)\end{array}$ \\
\hline Left/right & $\begin{array}{l}-0.02 \\
(0.13)\end{array}$ & $\begin{array}{l}0.06 \\
(0.09)\end{array}$ & $\begin{array}{l}-0.02 \\
(0.13)\end{array}$ & $\begin{array}{l}0.06 \\
(0.09)\end{array}$ & $\begin{array}{l}-0.02 \\
(0.13)\end{array}$ & $\begin{array}{l}0.06 \\
(0.09)\end{array}$ \\
\hline Nationalism & $\begin{array}{l}0.31 \\
(0.14) * *\end{array}$ & $\begin{array}{l}0.02 \\
(0.10)\end{array}$ & $\begin{array}{l}0.31 \\
(0.14)^{* *}\end{array}$ & $\begin{array}{l}0.02 \\
(0.10)\end{array}$ & $\begin{array}{l}0.31 \\
(0.14)^{* *}\end{array}$ & $\begin{array}{l}0.02 \\
(0.10)\end{array}$ \\
\hline Decentralization & $\begin{array}{l}-0.11 \\
(0.18)\end{array}$ & $\begin{array}{l}0.10 \\
(0.12)\end{array}$ & $\begin{array}{l}-0.11 \\
(0.18)\end{array}$ & $\begin{array}{l}0.10 \\
(0.12)\end{array}$ & $\begin{array}{l}-0.11 \\
(0.18)\end{array}$ & $\begin{array}{l}0.10 \\
(0.12)\end{array}$ \\
\hline Fiscal institutions index & $\begin{array}{l}-3.59 \\
(1.64)^{* *}\end{array}$ & $\begin{array}{l}-1.02 \\
(1.11)\end{array}$ & $\begin{array}{l}-3.59 \\
(1.64)^{* *}\end{array}$ & $\begin{array}{l}-1.02 \\
(1.11)\end{array}$ & $\begin{array}{l}-3.59 \\
(1.64)^{* *}\end{array}$ & $\begin{array}{l}-1.02 \\
(1.11)\end{array}$ \\
\hline Shock & $\begin{array}{l}-0.56 \\
(0.28)^{* *}\end{array}$ & $\begin{array}{l}-0.27 \\
(0.19)\end{array}$ & $\begin{array}{l}0.96 \\
(0.25)^{* * *}\end{array}$ & $\begin{array}{l}0.84 \\
(0.18)^{* * *}\end{array}$ & $\begin{array}{l}-0.45 \\
(0.20)^{* *}\end{array}$ & $\begin{array}{l}-0.32 \\
(0.14)^{* *}\end{array}$ \\
\hline Time dummies & $\mathrm{Y}$ & $\mathrm{Y}$ & $\mathrm{Y}$ & $\mathrm{Y}$ & $\mathrm{Y}$ & $\mathrm{Y}$ \\
\hline Country dummies & $\mathrm{Y}$ & $\mathrm{Y}$ & $\mathrm{Y}$ & $\mathrm{Y}$ & $\mathrm{Y}$ & Y \\
\hline Observations & 63 & 63 & 63 & 63 & 63 & 63 \\
\hline
\end{tabular}

Note: This table displays seemingly unrelated estimates of the fiscal outcome:

$y_{i t}=\alpha+\beta u_{t}+\gamma s_{i t}+\delta x_{i t}+\phi w_{i t}+v_{i}+\varepsilon_{i t}$

where $y_{i t}$ is the primary expenditure/revenue-to-GDP ratio in country $i$ and year $t ; v_{i}$ is a country specific component; $s_{i t}$ is the fiscal institutions index; $\mathrm{w}_{i t}$ are political control variables; and $x_{i t}$ are economic variables. $u_{t}$ represents variables common to all countries (EU 15 GDP growth, oil prices, German/France primary balance). Standard errors in parentheses; * significant at $10 \% ; * *$ significant at $5 \%$; *** significant at $1 \%$. 
Table 14. Expenditure and Revenue Developments: The Role of Economics and Politics, Evidence from Panel Data Regressions (Seemingly Unrelated Regressions Estimates)

\begin{tabular}{|c|c|c|c|c|c|c|}
\hline & \multicolumn{2}{|c|}{ EU15 growth shock } & \multicolumn{2}{|c|}{ Oil price shock } & \multicolumn{2}{|c|}{$\begin{array}{c}\text { German/France primary } \\
\text { balance }\end{array}$} \\
\hline & $\begin{array}{l}\text { Exp-to- } \\
\text { GDP }\end{array}$ & $\begin{array}{l}\text { Rev-to- } \\
\text { GDP }\end{array}$ & $\begin{array}{l}\text { Exp-to- } \\
\text { GDP }\end{array}$ & $\begin{array}{l}\text { Rev-to- } \\
\text { GDP }\end{array}$ & $\begin{array}{l}\text { Exp-to- } \\
\text { GDP }\end{array}$ & $\begin{array}{l}\text { Rev-to- } \\
\text { GDP }\end{array}$ \\
\hline Lagged expenditure & $\begin{array}{l}0.33 \\
(0.08)^{* * *}\end{array}$ & & $\begin{array}{l}0.34 \\
(0.08)^{* * *}\end{array}$ & & $\begin{array}{l}0.38 \\
(0.08)^{* * *}\end{array}$ & \\
\hline Lagged revenue & & $\begin{array}{l}0.26 \\
(0.08)^{* * *}\end{array}$ & & $\begin{array}{l}0.23 \\
(0.08)^{* * *}\end{array}$ & & $\begin{array}{l}0.26 \\
(0.08)^{* * *}\end{array}$ \\
\hline Unemployment rate & $\begin{array}{l}0.39 \\
(0.15)^{* * *}\end{array}$ & $\begin{array}{l}0.02 \\
(0.10)\end{array}$ & $\begin{array}{l}0.60 \\
(0.15)^{* * *}\end{array}$ & $\begin{array}{l}0.05 \\
(0.10)\end{array}$ & $\begin{array}{l}0.41 \\
(0.13) * * *\end{array}$ & $\begin{array}{l}0.08 \\
(0.08)\end{array}$ \\
\hline Inflation & $\begin{array}{l}-0.04 \\
(0.06)\end{array}$ & $\begin{array}{l}0.05 \\
(0.04)\end{array}$ & $\begin{array}{l}0.00 \\
(0.06)\end{array}$ & $\begin{array}{l}0.07 \\
(0.04)^{*}\end{array}$ & $\begin{array}{l}-0.02 \\
(0.06)\end{array}$ & $\begin{array}{l}0.05 \\
(0.04)\end{array}$ \\
\hline Openness & $\begin{array}{l}-3.57 \\
(3.67)\end{array}$ & $\begin{array}{l}1.43 \\
(2.56)\end{array}$ & $\begin{array}{l}-7.40 \\
(3.27)^{* *}\end{array}$ & $\begin{array}{l}1.79 \\
(2.20)\end{array}$ & $\begin{array}{l}-6.46 \\
(3.42)^{*}\end{array}$ & $\begin{array}{l}0.61 \\
(2.30)\end{array}$ \\
\hline $\begin{array}{l}\text { Government } \\
\text { fragmentation }\end{array}$ & $\begin{array}{l}1.27 \\
(2.08)\end{array}$ & $\begin{array}{l}1.80 \\
(1.45)\end{array}$ & $\begin{array}{l}2.33 \\
(1.99)\end{array}$ & $\begin{array}{l}2.02 \\
(1.36)\end{array}$ & $\begin{array}{l}1.91 \\
(2.20)\end{array}$ & $\begin{array}{l}1.99 \\
(1.51)\end{array}$ \\
\hline \multicolumn{7}{|l|}{ Government ideology: } \\
\hline Left/right & $\begin{array}{l}0.00 \\
(0.13)\end{array}$ & $\begin{array}{l}0.06 \\
(0.09)\end{array}$ & $\begin{array}{l}-0.02 \\
(0.12)\end{array}$ & $\begin{array}{l}0.05 \\
(0.09)\end{array}$ & $\begin{array}{l}-0.02 \\
(0.13)\end{array}$ & $\begin{array}{l}0.06 \\
(0.09)\end{array}$ \\
\hline Nationalism & $\begin{array}{l}0.32 \\
(0.14)^{* *}\end{array}$ & $\begin{array}{l}0.04 \\
(0.10)\end{array}$ & $\begin{array}{l}0.25 \\
(0.14)^{*}\end{array}$ & $\begin{array}{l}0.04 \\
(0.10)\end{array}$ & $\begin{array}{l}0.31 \\
(0.14)^{* *}\end{array}$ & $\begin{array}{l}0.02 \\
(0.10)\end{array}$ \\
\hline Decentralization & $\begin{array}{l}-0.29 \\
(0.21)\end{array}$ & $\begin{array}{l}0.03 \\
(0.15)\end{array}$ & $\begin{array}{l}-0.02 \\
(0.20)\end{array}$ & $\begin{array}{l}-0.01 \\
(0.13)\end{array}$ & $\begin{array}{l}-0.10 \\
(0.19)\end{array}$ & $\begin{array}{l}0.09 \\
(0.13)\end{array}$ \\
\hline Fiscal institutions index & $\begin{array}{l}-3.83 \\
(1.62) * *\end{array}$ & $\begin{array}{l}-0.92 \\
(1.11)\end{array}$ & $\begin{array}{l}-3.42 \\
(1.55) * *\end{array}$ & $\begin{array}{l}-0.84 \\
(1.05)\end{array}$ & $\begin{array}{l}-3.60 \\
(1.69)^{* *}\end{array}$ & $\begin{array}{l}-0.91 \\
(1.14)\end{array}$ \\
\hline Shock & $\begin{array}{l}-2.06 \\
(1.71)\end{array}$ & $\begin{array}{l}-1.54 \\
(1.19)\end{array}$ & $\begin{array}{l}0.46 \\
(0.53)\end{array}$ & $\begin{array}{l}1.30 \\
(0.36)^{* * *}\end{array}$ & $\begin{array}{l}-0.28 \\
(1.43)\end{array}$ & $\begin{array}{l}-0.64 \\
(0.96)\end{array}$ \\
\hline \multicolumn{7}{|l|}{ Interacted with : } \\
\hline District Magnitude & $\begin{array}{l}0.47 \\
(0.26)^{*}\end{array}$ & $\begin{array}{l}0.02 \\
(0.18)\end{array}$ & $\begin{array}{l}-0.07 \\
(0.05)\end{array}$ & $\begin{array}{l}-0.10 \\
(0.03)^{* * *}\end{array}$ & $\begin{array}{l}-0.02 \\
(0.20)\end{array}$ & $\begin{array}{l}-0.02 \\
(0.14)\end{array}$ \\
\hline Voter turnover & $\begin{array}{l}0.00 \\
(0.02)\end{array}$ & $\begin{array}{l}0.02 \\
(0.02)\end{array}$ & $\begin{array}{l}0.01 \\
(0.00)^{* *}\end{array}$ & $\begin{array}{l}0.00 \\
(0.00)\end{array}$ & $\begin{array}{l}-0.00 \\
(0.02)\end{array}$ & $\begin{array}{l}0.01 \\
(0.01)\end{array}$ \\
\hline Time dummies & $\mathrm{Y}$ & $\mathrm{Y}$ & $\mathrm{Y}$ & $\mathrm{Y}$ & $\mathrm{Y}$ & $\mathrm{Y}$ \\
\hline Country dummies & $\mathrm{Y}$ & $\mathrm{Y}$ & $\mathrm{Y}$ & $\mathrm{Y}$ & $\mathrm{Y}$ & $\mathrm{Y}$ \\
\hline Observations & 63 & 63 & 63 & 63 & 63 & 63 \\
\hline
\end{tabular}

Note: This table displays seemingly unrelated estimates of the fiscal outcome:

$y_{i t}=\alpha+\left(\beta+\phi z_{i}\right) u_{t}+\gamma s_{i t}+\delta x_{i t}+\phi w_{i t}+\left(v_{i}+\eta z_{i}\right)+\varepsilon_{i t}$

where $y_{i t}$ is the primary expenditure/revenue-to-GDP ratio in country $i$ and year $t$; $v_{i}$ is a country specific component; $s_{i t}$ is the

fiscal institutions index; $\mathrm{w}_{i t}$ are political control variables; $x_{i t}$ are economic variables; and $z_{i}$ are time-invariant institutional variables. $u_{t}$ represents variables common to all countries (EU 15 GDP growth, oil prices, German/France primary balance). Standard errors in parentheses; * significant at 10\%; ** significant at 5\%; *** significant at $1 \%$. 


\section{Construction of the Budget Institutions Index}

1. Following Gleich (2003), numerical indices were constructed by assigning values (ranging from 0 to 4 ) to the qualitative features of the budget institutions reported in Table 1, which characterized the three phases of the budget process: preparation, authorization, and implementation. The values have been assigned based on Gleich's survey and updated through information provided in Yläoutinen (2004), IMF fiscal ROSC reports, and through direct contact with the authorities.

2. Budget preparation stage. The institutional features considered are (i) fiscal rules that limit a priori the fiscal deficit; (ii) the establishment of quantitative budget targets based on a macroeconomic framework; and (iii) the relative power of the finance/prime minister in the budget negotiations. The following variables, shown in Table 1, are taken into consideration during this stage:

- Variable 1 refers to the strictness of permanent constraints on budgetary parameters, such as legal limits on the size of budget deficits or government borrowing.

- Variable 2 assesses control by the finance minister in setting fiscal targets and ceilings to guide the budget preparation.

- Variable 3 captures the power of the finance minister in compiling and negotiating the draft budget.

- Variable 4 reflects how remaining disputes from the bilateral negotiations are reconciled in the executive branch. Procedures in which the whole cabinet is involved are classified as more decentralized than procedures in which senior cabinet committees discussing the matter before it is presented to the whole cabinet.

3. Budget authorization stage. Given the common-pool dilemma, spending and deficit pressures can emerge if legislators are left unconstrained to amend the draft budget proposal. Therefore, institutional regulations that limit the scope of amendments to the budget proposal enhance discipline. The institutional characteristics considered are (i) explicit limits on the scope of amendments; (ii) the sequence of decision making in the authorization process; (iii) the relative power of the executive branch and the parliament; and the role of the president in this process. The four variables considered during the authorization stage follow (Table 1):

- Variable 5 regards formal constraints on the scope for the legislature to amend the government budget, and classifies processes as stricter if the amendments allowed are limited.

- Variable 6 refers to the sequence of decision making during the budget deliberation, and focuses on whether a decision is made on the size of major budget aggregates before details are worked out. 
- Variable 7 summarizes three institutional devices that reflect the strength of the executive branch (the government) vis-à-vis the parliament during the budget deliberation.

- Variable 8 captures the power of the president in the budget process; the less the power, the stronger implicitly the ability of the government in achieving its budget priorities.

4. Budget implementation stage. The first focus at this stage is on how binding the approved budget is. If the government can easily modify budget parameters, the agreements made in the preparation and implementation stages could be undermined and the authorization function of parliament weakened. Also, a degree of flexibility to react to unforeseen revenue shortfalls or spending overruns is necessary at the implementation phase. The variables considered during this stage are the following:

- Variable 9 gets a high score if parliament needs to approve a supplementary budget to institute changes. Similarly, Variable 10 gets a high score if transfers of allocations between ministries require parliamentary approval. Finally, in Variable 11, the inability to carry over of unused funds to the next year is regarded as conducive to discipline.

- With respect to the flexibility to react to unforeseen shocks, in Variable 12 the finance minister's ability to block expenditures is seen as the best option, with progressive weakening if expenditure blocking requires cabinet approval, parliamentary approval, or no approval at all.

On this basis, four indices were constructed for each country. Three refer to the quality of budget institutions in the three different stages of the budget process - preparation, authorization, and implementation - and the fourth that represents the overall index. Table 1 in this appendix reports the weights used in the aggregation to create the three component indices and the overall index. The variables are constructed as follows:

- Budget preparation index $=1 / 4 \sum_{i=1}^{4} x_{i}$

- $\quad$ Budget authorization index $=1 / 4 \sum_{i=5}^{8} x_{i}$

- Budget implementation index $=1 / 4 \sum_{i=10}^{13} x_{i}$

The overall index is calculated as the simple average of the three indices above. Appendix Table 2 shows the underlying measures on each of the sub-measures, indicating also the year in which a change occurred.

Delegation and contract-based indices. The indices for the delegation and contract-based approaches were obtained by summing up items of Table A1 that are relevant in those settings. 
The delegation-approach index was formed by items 2-7 and 9-12, which emphasize the role of a centralized fiscal authority. The contract-based index was constructed using items 1, 5-7, and 9-11, which highlight the presence of well informed and transparent rules (the role of the minister of finance remains in this approach but mainly to monitor and enforce pre-existing contracts rather taking a pro-active role in the formation of the budget) . 
Table A1. Construction of the Index: Fiscal Institutions and Their Index Parameters

\begin{tabular}{|c|c|c|c|c|}
\hline & \multicolumn{2}{|c|}{ Weighting factors } & \multirow[b]{2}{*}{ Item } & \multirow[b]{2}{*}{$\begin{array}{l}\text { Numerical } \\
\text { coding }\end{array}$} \\
\hline & Index & $\begin{array}{l}\text { Sub- } \\
\text { index }\end{array}$ & & \\
\hline A. Preparation & 0.33 & & & \\
\hline 1. Existence of statutorily mandated fiscal rules & & 0.25 & & \\
\hline a. Balanced budget rule. & & & & 4.00 \\
\hline b. Limits on public borrowing. & & & & 2.00 \\
\hline c. No legal limits on borrowing. & & & & 0.00 \\
\hline 2. Sequence of budgetary decision making & & 0.25 & & \\
\hline $\begin{array}{l}\text { a. MF sets forth aggregate and specific budget targets in initial budget circular } \\
\text { b. MF proposes, cabinet decides on targets for budget aggregates and spending }\end{array}$ & & & & 4.00 \\
\hline $\begin{array}{l}\text { limits are assigned to each ministry before spending ministries develop } \\
\text { budget requests. }\end{array}$ & & & & 3.00 \\
\hline $\begin{array}{l}\text { c. MF proposes, cabinet decides on targets for budget aggregates before } \\
\text { spending ministries develop budget requests. }\end{array}$ & & & & 2.00 \\
\hline d. Budgetary targets are set on the basis of preliminary budget requests. & & & & 1.00 \\
\hline e. No budget targets are determined. & & & & 0.00 \\
\hline 3. Compilation of the draft budget & & 0.25 & & \\
\hline a. Finance ministry holds bilateral negotiations with each spending ministry. & & & & 4.00 \\
\hline b. Finance ministry holds bilateral negotiations, other parties included. & & & & 2.00 \\
\hline $\begin{array}{l}\text { c. Finance ministry only collects budget requests and compiles summary for } \\
\text { cabinet session. }\end{array}$ & & & & 0.00 \\
\hline 4. Members of executive responsible for reconciling conflicts over budget bids & & 0.25 & & \\
\hline a. MF or PM can veto or overrule cabinet decision. & & & & 4.00 \\
\hline b. Senior cabinet committee, then whole council of ministers or cabinet. & & & & 2.00 \\
\hline c. Executive collectively (e.g., council of ministers or cabinet). & & & & 0.00 \\
\hline \multicolumn{5}{|l|}{ B. Legislation } \\
\hline 5. Constraints on the legislature to amend the government's draft budget & & 0.25 & & \\
\hline $\begin{array}{l}\text { a. Deficit provided in the draft budget cannot be exceeded, or } \\
\text { individual amendments have to indicate offsetting changes. }\end{array}$ & & & & 4.00 \\
\hline b. No restrictions. & & & & 0.00 \\
\hline 6 . Sequence of votes & & 0.25 & & \\
\hline a. Initial vote on total budget revenues, expenditures, and the deficit. & & & & 4.00 \\
\hline b. Final vote on budget aggregates. & & & & 0.00 \\
\hline 7. Relative power of the executive vis-à-vis the parliament & & 0.25 & & \\
\hline a. Cabinet can combine a vote of confidence with a vote on the budget. & & & 0.33 & 4.00 \\
\hline $\begin{array}{l}\text { b. Draft budget is executed if parliament fails to adopt the budget before the } \\
\text { start of the fiscal year. }\end{array}$ & & & 0.33 & 4.00 \\
\hline c. Parliament can be dissolved if it fails to adopt the budget in due time. & & & 0.33 & 4.00 \\
\hline 8. Authority of the national president in the budget procedure & & 0.25 & & \\
\hline a. No special authority. & & & & 4.00 \\
\hline b. President has veto right (president elected by parliament). & & & & 2.67 \\
\hline c. President has veto right (president directly elected by citizens). & & & & 1.33 \\
\hline d. President has veto right (qualified majority required to override veto). & & & & 0.00 \\
\hline C. Implementation & 0.33 & & & \\
\hline 9. Flexibility to change budget aggregates during execution. & & 0.25 & & \\
\hline $\begin{array}{l}\text { a. Any increase in total revenues, expenditures and the deficit needs to be } \\
\text { approved by parliament in a supplementary budget. }\end{array}$ & & & & 4.00 \\
\hline b. Revenue windfalls can be used to increase expenditure without the approval & & & & \\
\hline $\begin{array}{l}\text { of parliament as long as the deficit is not increased. } \\
\text { c. Simultaneous changes in revenue and expenditures allowed without }\end{array}$ & & & & 2.67 \\
\hline approval of parliament if budget balance is not changed. & & & & 1.33 \\
\hline d. At total or large discretion of government. & & & & 0.00 \\
\hline 10. Transfers of expenditures between chapters (i.e. ministries' budgets) & & 0.25 & & \\
\hline a. Require approval of parliament. & & & & 4.00 \\
\hline b. FM or cabinet can authorize transfers between chapters. & & & & 2.67 \\
\hline c. Limited. & & & & 1.33 \\
\hline d. Unrestricted. & & & & \\
\hline 11. Carryover of unused funds to next fiscal year & & 0.25 & & \\
\hline a. Not permitted. & & & & 4.00 \\
\hline b. Only if provided for in initial budget or with finance ministry approval. & & & & 2.67 \\
\hline c. Limited. & & & & 1.33 \\
\hline d. Unlimited. & & & & 0.00 \\
\hline 12. Procedure to react to a deterioration of the budget deficit (due to unforeseen & & & & \\
\hline revenue shortfalls or expenditure increase) & & 0.25 & & \\
\hline a. MF can block expenditures & & & & 4.00 \\
\hline b. The cabinet can block expenditures. & & & & 2.67 \\
\hline c. Approval of the parliament necessary to block expenditures. & & & & 1.33 \\
\hline d. No action is taken. & & & & 0.00 \\
\hline
\end{tabular}




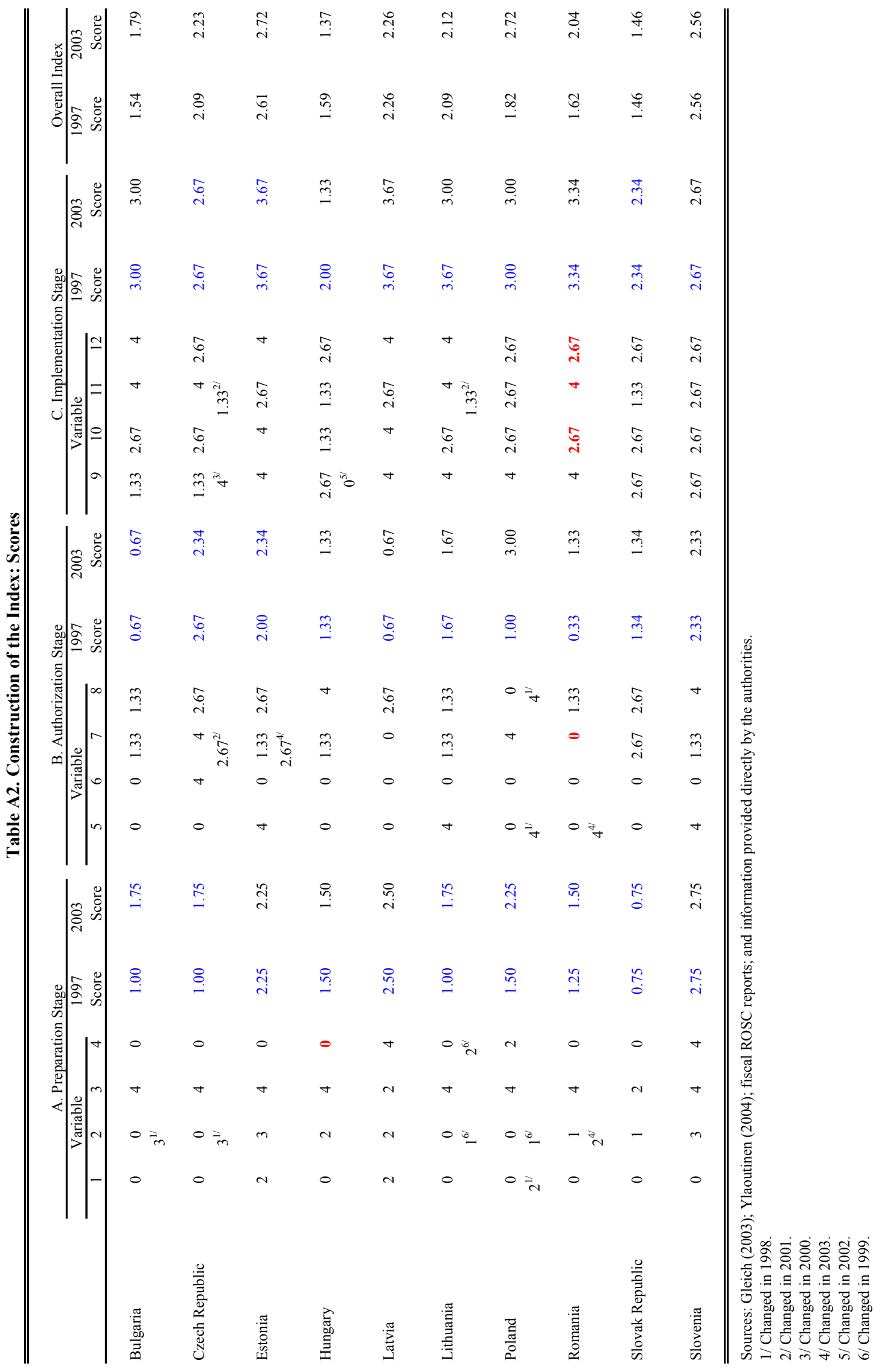




\section{Variables and Data Sources}

\section{Dependent Variables}

For the fiscal outcome, the general government primary balance is considered. Data from the fiscal notifications to the European Commission are used. Total revenue and grants and total expenditure and net lending minus interest payments are also considered in the analysis. Since these data are not available for all countries in the sample from the fiscal notifications, data from the IMF World Economic Outlook (WEO) database are used.

\section{Time-Varying Economic Conditioning Variables}

Public debt as percent of GDP (lagged); unemployment rate; openness index (imports plus exports normalized by GDP); output gap, applying the Hodrick-Prescott filter to GDP data. These are based on data from the IMF's World Economic Outlook.

Dummy for an IMF program, taking value 1 if the country had a program with the Fund during that year, 0 otherwise.

Dummy for the preparation to EU accession, taking a value of 1 from the year the country was invited to start the negotiations on aquis communitaire chapters.

France/Germany primary balance is the average of the lagged primary balances in France and Germany. Data are from the EUROSTAT database.

\section{Time-Varying Political Variables}

\section{Government fragmentation}

This variable is constructed as the Herfindhal index, constructed as the sum of squares of the shares of each party in the government coalition. The index ranges in value from 0 (in the case of very fragmented coalitions to 1 (if one party forms the government).

Data sources: Database on Political Institutions, 2000 (updated in 2004) http://www.worldbank.org/research/bios/pkeefer.htm; Parties and Elections in Europe, www.parties-and-elections.de; and Economist Intelligence Unit reports.

\section{Ideological orientation of governing coalitions}

Three dimensions are used to characterize the ideological orientation of the government coalition. These relate to: (a) left/right orientation, with a larger value indicating a greater leaning to the right; (b) nationalism, (promotes a national rather than cosmopolitan consciousness, history, and culture); and (c) centralization (opposes any decentralization of administration and decision-making). For each dimension, the government coalition's ideological position is estimated as the sum of each party's position, weighted by the party's seats in parliament. 
Data source: Database on Party Policy in Modern Democracies by Benoit and Laver (2005) http://www.politics.tcd.ie/ppmd/, which quantifies the position with respect these and other dimensions for all parties in 47 countries.

Dummy assuming a value of 1 for the year of elections, 0 otherwise.

\section{Fiscal institutions indices}

These variables are described in Appendix I.

Sources: Gleich (2003), Yläoutinen (2004), IMF fiscal ROSC reports, and direct information from the authorities.

\section{Ethnic fractionalization}

The variable is constructed as one minus the sum of squares of the shares of identified ethnic groups. If the country has only one ethnic group, the value of the index is zero; as the number of ethnic groups increases, the index of fractionalization increases to 1 .

Source: Alesina and others (2003) http://www.stanford.edu/ wacziarg/papersum.html

\section{District magnitude}

The number of representatives elected by a single district.

Data source: Database on Political Institutions, 2000 (updated in 2004)

http://www.worldbank.org/research/bios/pkeefer.htm;

\section{Voter turnout}

Voter turnout as percent of voting age population (see Mueller and Stratmann, 2002).

Data source: Institute for Democracy and Electoral Assistance

http://www.idea.int/vt/index.cfm 